\title{
THE USE OF COERCIVE PUBLIC HEALTH AND HUMAN BIOSECURITY LAW IN AUSTRALIA: AN EMPIRICAL ANALYSIS
}

\author{
DAVID J CARTER*
}

The powers available to the state in the name of advancing or protecting the public's health are extensive and highly elastic. Drawing on the findings of an empirical project on the use of public health law in Australia, this article provides an account of their use by Australian state and territory governments. The research reported here reveals some serious concerns about the use of these powers. This includes evidence of the indefinite detention of multiple individuals by public health authorities, including those detained until their death, and public health orders made without time limits and never rescinded. The overarching claim made by this article is that the use of coercive public health and biosecurity legal powers in Australia is active but not currently accompanied by sufficient transparency. This lack of publicly available information must be rebalanced in light of the strong public interest arguments for transparency and accountability.

\section{INTRODUCTION}

Public health and human biosecurity practices aim to prevent and control the onward transmission of communicable disease and other risks to the public health within a particular population or jurisdiction. Some longstanding public

* $\quad$ Senior Lecturer in Law and National Health and Medical Research Council Early Career Fellow, Faculty of Law, University of Technology Sydney, Australia. Visiting Researcher at the Brocher Foundation. Funding for this research was provided by the Law, Health, Justice Research Centre of the UTS Faculty of Law and was supported by the Brocher Foundation (www.brocher.ch) and the National Health and Medical Research Council ('NHMRC') (Grant ID: 1156520). The contents are solely the responsibility of the individual author and do not reflect the views of NHMRC. Ethics approval for relevant elements of this research was granted by the UTS Human Research Ethics Committee (2015000191). I especially acknowledge Distinguished Professor Jenni Millbank and Distinguished Professor Isabel Karpin for their invaluable advice, as well as Dr Elyse Methven, Dr Anthea Vogl for assistance in relation to Freedom of Information processes and Dr C Starla Hargita and Emile Carreau for research assistance early in the project. I acknowledge the various public health and FOI officers for their assistance in processing both administrative and FOI requests. An earlier version of this research was presented at the Centre for Health Law and Society, La Trobe Law School and the Centre for Health Economics Research and Evaluation in their seminar series. 
health and human biosecurity practices are highly coercive. These practices rely upon powers created by public health and human biosecurity law found in a network of legislative and regulatory regimes across the nation. These laws authorise the executive to compel a person to undergo medical testing or treatment, to compel particular persons to engage in or refrain from particular behaviours or to limit their free movement, including through the power to involuntarily isolate or quarantine a person or group of persons including by the use of force. These coercive powers are applied by way of what are commonly referred to as 'public health orders'; orders that are similar to the more familiar involuntary treatment orders in the mental health context. These are orders issued in almost all cases by the executive, following an administrative decision undertaken by decision-makers that are generally the Chief Health Officer or Chief Public Health Officer of a particular state or territory - who usually delegate this power to a range of other persons.

Information relating to the use of these coercive public health and human biosecurity powers in Australia has been sporadically available at best. The principal source of information has been individual cases that raise such sufficient controversy that they come to the public's attention. There are two cases that have reached that level of public attention, that of Sharleen Spiteri and Lam Kuoth. The details of these cases are the most substantial entry point into the individual experience of coercive public health and human biosecurity powers available on the public record. They are outlined here as a way of better understanding the nature of these powers, and to establish what we know of the nature and character of their use in Australia.

The case of Sharleen Spiteri is the best documented case. Spiteri was a sex worker, who was living with HIV. In 1989, Spiteri appeared on the current affairs program 60 Minutes and told reporter Jeff McMullen that she tried to get her clients to practise safe(r) sex, but sometimes they refused to wear condoms. ${ }^{1}$ When reported, McMullen described Spiteri as "more dangerous than a serial killer'. ${ }^{2}$ The following morning, Spiteri was arrested and was held in various forms of public health detention for approximately 16 years, that is, from 1989 through to 2005. This detention took place in empty hospital wards, rented houses and institutions, and involved 24-hour supervision provided by nursing and security staff. It led, eventually, to detention in a supported accommodation facility for those living with HIV and who had street-based lifestyles known as 'badlands' in Sydney. Here, Spiteri was locked behind a metal grate, while other residents in the facility - all of whom had HIV and many of whom were engaged in sex work, including unsafe sex - were free to leave and to work as they saw fit.

Tom Morton and Eurydice Aroney, academic journalists who presented a landmark documentary on Sharleen's story, argued that 12 of those years of

1 See especially 'Shutting Down Sharleen', Hindsight (ABC Radio National, 21 March 2010) $<$ http://www.abc.net.au/rn/hindsight/stories/2010/2848373.htm>; Tom Morton, "“Dirty Little Secret": Journalism, Privacy and the Case of Sharleen Spiteri' (2012) 18(1) Pacific Journalism Review 46. 
detention were imposed without legal sanction. ${ }^{3}$ After the New South Wales ('NSW') Department of Health released information on orders relating to Spiteri made under their public health powers, the information showed only two orders having been made: one from 1989 and another from 2001. This left a 12-year period without orders being made. ${ }^{4}$ When questioned, the Department provided a statement saying that

[i]ntensive supervision outside the framework of a Public Health Order is provided with the consent of the client concerned [Spiteri]. Providing more detail would involve release of personal health information of Ms Spiteri and release could be contrary to new privacy laws. ${ }^{5}$

Spiteri died in 2005 following 16 years of public health detention, most of which appeared to be unlawful. ${ }^{6}$ As a final indignity, the public health order was sticky taped to the wall above her bed in the hospice while she lay dying.

There are serious questions regarding the potentially unlawful and arbitrary nature of Spiteri's detention by the state. The state itself admits that her detention was undertaken 'outside the framework of a Public Health Order' ${ }^{7}$ - that is, outside of the law that enables and sets limits and safeguards around the exercise of these powers. Moreover, what we know of the enactment of her detention shows a healthcare system exercising arbitrary coercive control of a vulnerable person in ways directly contradictory with its own management of other persons in exactly the same situation, even within the same facility. Given the existence of the supported accommodation facility, Sharleen's behaviours and the risk they presented were clearly not exceptional. And yet, the regime of public health laws structured and justified by the exceptional nature of a serious threat to the public health were used here, for 16 years, in response to them. Perhaps most concerningly, Spiteri's case speaks to a public health system and associated ways of thinking and acting that was able to sustainably operate in these arbitrary and potentially unlawful ways, doing so in such stark incongruity with dominant discourse of rights-based risk reduction that marks out the most successful parts of Australia's public health approaches to HIV and other communicable diseases. For the avoidance of doubt, what this looks like 'on the ground', as it were, are health professionals within these spaces who could lock the door to Spiteri's 'cell', while simultaneously engaging with other residents around the same behaviours that justified Spiteri's detention, but somehow, not theirs.

Cases like this are not limited to the height of the HIV/AIDS crisis. A more recent example is that surrounding Lam Kuoth in Victoria. ${ }^{8}$ Whilst receiving treatment for tuberculosis ('TB') in late 2006, testing had revealed that Kuoth was HIV-positive. After some non-attendance at subsequent appointments and

3 Ibid.

4 Ibid.

5 Email from Jason Donohoe, 18 February 2010, reproduced in 'Shutting Down Sharleen' (n 1) and Morton (n 1) 63

6 'Shutting Down Sharleen' (n 1).

$7 \quad$ As cited in 'Shutting Down Sharleen' (n 1) and Morton (n 1) 63.

8 David J Carter, 'HIV Transmission, Public Health Detention and the Recalcitrant Subject of Discipline: Kuoth, Lam v R and the Co-Constitution of Public Health and Criminal Law' (2016) 25(2) Griffith Law Review 172, 191 ('HIV Transmission'). 
elevated concern for his behaviour, the Victorian Chief Health Officer made a public health order requiring him to disclose his HIV status to any sexual partner and to use condoms during sexual intercourse. It was after this order that Kuoth engaged in sexual intercourse without the use of a condom and without disclosing his HIV status. This was to be the basis of a criminal prosecution of Kuoth for an HIV transmission-related offence. ${ }^{9}$

Shortly after the commission of what was to become Kuoth's criminal offence, the Victorian Chief Health Officer issued a public health order, specifically, a 28-day isolation order. The isolation order was renewed every 28 days for a total of 16 months. The isolation order issued to Kuoth was total. Kuoth was required to be isolated in an empty ward, directly supervised at all times by one nurse and two security guards. He had no visitors, and any movement required prior approval by the Chief Health Officer. After almost four months, Kuoth was then relocated by order to a suburban house, where he remained under 24-hour surveillance, with staff monitoring his movements 'assisted by video surveillance'. ${ }^{10}$ In May 2008, there was a relaxation of the order, allowing for five minutes per 24 hours of indirectly supervised time. Visitors still had to be supervised, and two security staff had to be present at all times for participation in study or attendance at job interviews.

In a later appeal of his criminal sentence, the Victorian Court of Appeal found that the administrative detention to which Kuoth had been subject - a 16month involuntary civil detention under public health powers - constituted 'imprisonment' for the purposes of the subsequent criminal sentence. They said that

the appellant has already served what amounts to a term of imprisonment for this offending. It is true that he was under civil detention and not in a gaol. But, plainly enough, the essence of imprisonment is the deprivation of liberty. ${ }^{11}$

In relation to HIV in particular, the public health discipline has been of one voice regarding the inappropriateness of criminal law and criminal procedures in relation to transmission of HIV. ${ }^{12}$ Public health advocates argue that the criminal law's practices are incompatible with public health approaches, that the threat of criminal law's punishment undermines effective transmission reduction efforts, and that the transmission of HIV is not worthy of the constraint or deprivation of liberty that is the result of criminal liability. Yet as these cases show, public health practice uses the very same technologies of constraint and deprivation of liberty, and uses them - at least in the cases we know about - in a manner that

$9 \quad R v$ Kuoth (County Court of Victoria, Lacava J, 11 August 2008); Kuoth, Lam v R [2010] VSCA 103.

10 Kuoth, Lam v R [2010] VSCA 103, [6] (Maxwell P).

11 Ibid [18].

12 Scott Burris and Edwin Cameron, 'The Case against Criminalization of HIV Transmission' (2008) 300(5) Journal of the American Medical Association 578; 'The criminalization of HIV has been a strange, pointless exercise in the long fight to control HIV': Matthew Weait, Intimacy and Responsibility: The Criminalisation of HIV Transmission (Routledge-Cavendish, $1^{\text {st }}$ ed, 2007), 1, quoting Scott Burris et al, 'Do Criminal Laws Influence HIV Risk Behavior? An Empirical Trial' (2007) 39(2) Arizona State Law Journal 467, 516. See also the mutual incompatibility of criminal law and public health approaches that marks much of the Australian literature on the question described here: Carter, 'HIV Transmission' (n 8) 180-3. 
raises significant questions regarding the appropriate balance between the individual liberty and communal public health.

Most scholarship and state discourse surrounding communicable disease control is in broad agreement on the need for effective public health and human biosecurity legal mechanisms as a key element in state responses to communicable disease. However, very little has been written about the use of these powers. In Australia, their exercise is not routinely made public and there are no comprehensive, accessible sources of information on how these powers have been used over time, nor indeed how they combine to form a matrix of coercive public health activities across the nation. The cases of Spiteri and Kuoth are two of the very limited set of cases that have made it into the public arena. Given the concerning nature of what we know about the use of these powers, the question naturally arises: how many of these orders are being made, and more importantly, are the cases of Spiteri and Kuoth 'outliers' in the way in which public health orders are used and administered - or are they somehow 'representative' of practice in this area? ${ }^{13}$

The article proceeds in two further parts. Part II focuses on the issue of coercive public health practices in the public health context, briefly presenting the justifications and attendant critiques of their use as a mechanism of communicable disease control. This is followed by an account of the various state, territory and Commonwealth public health and biosecurity regimes (with a particular focus on their more coercive aspects) by way of contextualising the remainder of the article. Part III reports on the use of public health powers in Australia. This Part proceeds by first providing a brief account of the methods of public information audit, administrative engagement and freedom of information ('FOI') processes used to collect data on the use of public health and biosecurity powers in Australia, including, especially, a reflection on the limitations and difficulties encountered during the project's data collection phase. The analysis demonstrates, first, that public health's coercive powers are actively used, despite having almost no presence in official, scholarly or professional discussions of public health practice in this country, resulting in an absence of critical attention as to whether they are working as designed. Secondly, the analysis demonstrates that there exists significant, albeit not necessarily problematic, variation in practice between jurisdictions, with different legal and regulatory schemes accompanied by varying rates of use of coercive powers. Finally, the analysis reveals that there is a lack of publicly available information and reporting on the objectives, outcomes, process and procedure of the use of coercive public health and human biosecurity powers by the state. I conclude by arguing that this lack of publicly available information must be rebalanced in light of the strong public interest arguments for transparency and accountability and the positive effects

13 This work of collecting and analysing the use of public health powers naturally raises a series of normative questions. However, whether or not such coercive powers are justified on ethical or other grounds, or require specific types of reform, is beyond the scope of this article. I refer to some of the perspectives regarding the normative aspects of these powers, their justifiability, and other like questions below. 
that transparency can bring about for both public health practice and the rule of law in relation to the use of coercive public health powers.

\section{COERCIVE PUBLIC HEALTH PRACTICES AND LAW}

This Part of the article presents an overview of coercive public health practices. It presents a picture of their clinical context and use followed by a presentation of the attendant justifications and tensions surrounding their availability as a mechanism of communicable disease control. This is followed by an account of the state, territory and Commonwealth public health and biosecurity laws which authorise these coercive practices.

\section{A Coercive Public Health Powers in the Public Health Context}

Law comes to directly operate in the field of public health through public health and human biosecurity law that establishes powers and authorises processes related to communicable disease audit and surveillance, laboratory detection, epidemiological investigation, microbial and disease classification, and infection prevention and control, including isolation, quarantine, involuntary testing and treatment. ${ }^{14}$ The coercive aspects of these public health and human biosecurity practices and their authorisation in law are commonly justified by reference to their efficacy in preventing and controlling the onward transmission of communicable disease within a particular population or jurisdiction. ${ }^{15}$ However, with the availability and use of these legal powers arises the problem of 'how to square individual freedom with the public good" ${ }^{16}$ of communicable disease control. ${ }^{17}$

There is a sustained tradition of debate regarding the use of public health powers. This tradition emerges from the core tensions and 'trade-offs' in public

14 Despite significant scholarly and professional discussion, 'public health law', at least as its stands at present in Australia, retains a distinctive focus on communicable disease transmission. So-called 'public health law' interventions that focus on non-communicable disease (like obesity) are in their infancy when it comes to formal lawmaking.

15 There is a much larger and more developed literature in relation to the more extensive use of detention, community treatment orders and other forms of coercive power in relation to those living with mental health conditions and disabilities. See, eg, Terry Carney et al, Australian Mental Health Tribunals: Space for Fairness, Freedom, Protection \& Treatment? (Themis Press, 2011); Linda Steele, 'Disabling Forensic Mental Health Detention: The Carcerality of the Disabled Body' (2017) 19(3) Punishment \& Society 327; Linda Roslyn Steele, 'Troubling Law's Indefinite Detention: Disability, the Carceral Body and Institutional Injustice' (2018) XX(X) Social \& Legal Studies (advance).

16 Dorothy Porter and Roy Porter, 'The Enforcement of Health: The British Debate' in Elizabeth Fee and Daniel M Fox (eds), AIDS: The Burdens of History (University of California Press, 1988) 97, 97.

17 As Dorothy Porter and Roy Porter put it, the rise of public health or 'state medicine' in the $19^{\text {th }}$ century produced 'a striking infringement of the traditional freedom to be sick, and to spread one's sickness, with impunity': Porter and Porter (n 16) 104, 108. This is echoed in more recent scholarship regarding public health, with Mooney arguing that that the complex nexus of practices that public health enacts tends toward coercion and unwanted interference: see generally Graham Mooney, Intrusive Interventions: Public Health, Domestic Space, and Infectious Disease Surveillance in England, 1840-1914 (Boydell \& Brewer, 2015) 5, $71 \mathrm{ff}$. 
health practice and ethics between individual and collective. This debate has played out in different contexts to differing conclusions. For example, the use of the most coercive public health powers like involuntary testing, treatment or detention, has not been supported by the mainstream of writing on public health approaches to HIV. In that context, where normative arguments for the use of coercive practices have been advanced, both normative and instrumental ('effectiveness') arguments has been mobilised against coercion. Mandatory or coercive testing, for example, has been consistently rejected based upon claims it would cause an active deterrent for individuals, driving them away from testing and treatment services and thus preventing effective action on HIV prevention and control. ${ }^{18}$ Given this, preferred responses to HIV have been those marked by voluntary engagement, solidarity, reciprocity and other like approaches, generally framed as a human rights-based public health response. ${ }^{19}$ This is true of the Australian approach, which has been regarded as highly successful. ${ }^{20}$ Beyond HIV, there is an active scholarship that considers the same set of concerns in relation to other communicable conditions, including $\mathrm{TB}^{21}$

As to specifically legal scholarship, the work of British legal scholar Matthew Weait has advanced some of the most important arguments relating to HIV and the law. This is especially so in his work advancing a critique of the application of criminal law in this area. ${ }^{22}$ However, in relation to public health laws, specifically, Weait has also argued that

public health law may - rather than being a 'soft option' - amount to criminalisation by the back door, and that its coercive potential not only threatens the human rights of [people living with HIV/AIDS] but may actually impede the effective management of the epidemic. ${ }^{23}$

18 See, eg, Barr, Amon and Clayton who summarise the generally articulated view of mandatory and coercive approaches: David Barr, Joseph J Amon and Michaela Clayton, 'Articulating a Rights-Based Approach to HIV Treatment and Prevention Interventions' (2011) 9(6) Current HIV Research 396.

19 For a review of the history and transformation of human rights-based approaches globally, see Benjamin Mason Meier, Kristen Nichole Brugh and Yasmin Halima, 'Conceptualizing a Human Right to Prevention in Global HIV/AIDS Policy' (2012) 5(3) Public Health Ethics 263. 'Human rights' has figured in all Australian HIV strategies and remains the case today as a '[g]uiding principle': see Department of Health (Cth), Eighth National HIV Strategy 2018-2022 (Report No 8, 2018) 8.

20 William Bowtell, Australia's Response to HIV/AIDS 1982-2005 (Report, Lowy Institute for International Policy, May 2005) 6-7.

21 See, eg, Michael J Selgelid, 'Ethics, Tuberculosis and Globalization' (2008) 1(1) Public Health Ethics 10; Richard Coker, From Chaos to Coercion: Detention and the Control of Tuberculosis (St. Martin's Press, 2000) ('From Chaos to Coercion'); Richard Coker, 'Tuberculosis, Culture and Coercion' (2000) 10(3) European Journal of Public Health 223; Richard James Coker, 'Public Health Impact of Detention of Individuals with Tuberculosis: Systematic Literature Review' (2003) 117(4) Public Health 281; Chris Degeling et al, 'Eliminating Latent Tuberculosis in Low-Burden Settings: Are the Principal Beneficiaries to Be Disadvantaged Groups or the Broader Population?' (2017) 43(9) Journal of Medical Ethics 632; Diego S Silva, Angus Dawson and Ross EG Upshur, 'Reciprocity and Ethical Tuberculosis Treatment and Control' (2016) 13(1) Journal of Bioethical Inquiry 75; Barron H Lerner, 'Catching Patients: Tuberculosis and Detention in the 1990s' (1999) 115(1) Chest 236; Chris Degeling et al, 'The Political and Ethical Challenge of Multi-Drug Resistant Tuberculosis' (2015) 12(1) Journal of Bioethical Inquiry 107.

22 See especially Weait (n 12).

23 Ibid 3. See also ibid 12, 19, $120 \mathrm{ff}$. 
Such caution regarding coercive public health practices is shared by the specifically Australian legal scholarship on the topic. Recent scholarship has highlighted the mutually reinforcing interface between public health practices and the criminal legal apparatus ${ }^{24}$ other work has raised 'important issues about the cultural and ethical acceptability of [pandemic] planning measures' ${ }^{25}$ These concerns are echoed in work on the relatively new frontier of non-communicable disease prevention and control, where 'rights-oriented consumer groups have decried some measures because they impinge on civil liberties', ${ }^{26}$ and by important historical and bioethical scholarship that looks to Australia's historical and continued 'practising [of a] a settler colonial biopolitics of the population, ${ }^{27}$ enacted through the conduct of law.

The experience of those who are made subject to involuntary detention and treatment is little studied, and yet, where reported, presents an understandably tense, complex and ultimately unsatisfactory picture. Researchers in NSW report two case studies of patients who were subject to detention for TB-related isolation and treatment under that state's public health Act. $^{28}$ Those patients were described as being 'extremely unhappy about being detained'. ${ }^{29}$ The reports note that 'Patient 1 stopped eating and lost weight while detained. Patient 2 considered his room to be a "jail cell". He also stated that he was frustrated and that his human rights were being "infringed". ${ }^{30}$ The detention in both cases was not straightforward. Instead, both cases involved multiple and overlapping coercive measures and multiple state and non-state actors. In one of the two case studies, treating teams notified, amongst others, Commonwealth immigration authorities (who placed a 'trace' on Patient 1's mobile phone), while also choosing to directly request the assistance of Chinese consular officials in efforts to locate the patient who had absconded. It was Chinese consular officials who did eventually locate and return the patient to hospital for treatment, whereupon Australian immigration officials made plans to relocate the patient into immigration detention whilst still with active TB.

24 Carter, 'HIV Transmission' (n 8); Sally Cameron, 'Criminal Law in Clinical Settings: Guarding against the Big Chill' (2016) 14(2) HIV Australia 45.

25 Belinda Bennett and Terry Carney, 'Law, Ethics and Pandemic Preparedness: The Importance of CrossJurisdictional and Cross-Cultural Perspectives' (2010) 34(2) Australian and New Zealand Journal of Public Health 106, 106. See also Terry Carney, Richard Bailey and Belinda Bennett, 'Pandemic Planning as Risk Management: How Fared the Australian Federation?' (2012) 19(3) Journal of Law and Medicine 550; Belinda Bennett, Terry Carney and Richard Bailey, 'Emergency Powers \& Pandemics: Federalism and the Management of Public Health Emergencies in Australia' (2012) 31(1) University of Tasmania Law Review 37 ('Emergency Powers \& Pandemics').

26 Michelle M Mello, David M Studdert and Troyen A Brennan, 'Obesity: The New Frontier of Public Health Law' (2006) 354(24) New England Journal of Medicine 2601, 2601.

27 Ben Silverstein, "'Possibly They Did Not Know Themselves": The Ambivalent Government of Sex and Work in the Northern Territory Aboriginals Ordinance 1918' (2017) 14(3) History Australia 344, 399. See also Ben Silverstein, 'From Population to Citizen: The Subjects of the 1939 Aboriginal New Deal in Australia's Northern Territory' (2011) 22 Kontur 17, 25-6; Christopher Mayes, Unsettling Food Politics: Agriculture, Dispossession and Sovereignty in Australia (Rowman \& Littlefield International, 2018). Sanjaya N Senanayake and Mark J Ferson, 'Detention for Tuberculosis: Public Health and the Law' (2004) 180(11) Medical Journal of Australia 573. Ibid 574. Ibid. 
The authors of these two Australian case studies reproduce and reflect upon the detention experiences of patients during New York's TB epidemic of the 1990s. They described how (particular) patients in New York 'eventually expressed gratitude to the city authorities for detaining them: "the chaos of their lives had been transformed into a calm in which they could reflect upon their life's course". ${ }^{31}$ The language used to describe the patients in New York is striking. For one, it bears a marked resemblance to the classic trope of penal discourse regarding solitary confinement that emerged, like contemporary public health practice, in the $19^{\text {th }}$ century. Under the guise of reforming criminals, '[i]t was believed that once left alone [in solitary confinement] with their conscience and the Bible, prisoners would engage in inner reflection, see the error of their ways and be reformed into law abiding citizens' ${ }^{32}$ That this submission-salvation narrative is offered by way of contrast with the resistance of the two NSW patients to their detention is similarly striking. Thankfully, the authors of the NSW study note that '[o]f course, other patients [detained in New York] did not look so favourably on their detention'. ${ }^{33}$

Significant work is still needed to advance critical engagement with these powers. Yet, in that vein, Dorothy Porter and Roy Porter once wrote that discussions surrounding the tension between the public good and individual freedom in this field have been 'all too often ... emotional, even hysterical' ${ }^{34}$ Porter and Porter suggested that attending to the tension between the public good and individual freedom with "philosophical rigor, a sense of historical context, and social realism ${ }^{35}$ was potentially an antidote to such a situation. ${ }^{36}$ While

31 Ibid, quoting Richard Coker's work, who describes this attitude as being expressed by '[m]any noncompliant patients': Richard Coker, 'Just Coercion? Detention of Nonadherent Tuberculosis Patients' (2001) 953b(1) Annals of the New York Academy of Sciences 216, 217. See also From Chaos to Coercion (n 21).

32 Sharon Shalev, A Sourcebook on Solitary Confinement (Sourcebook, October 2018) 2. On this, see the excellent and engaging work by Joshua Dubler, who writes, 'At Philadelphia's famed Eastern State Penitentiary, which opened in 1829 , the aspiration of holy encounter was literalized architecturally with the placement of skylights - "eyes of God" - through which the sequestered prisoner might come to see himself as the Almighty saw him, slough off his sin, and repent': Joshua Dubler, Down in the Chapel: Religious Life in an American Prison (Farrar, Straus and Giroux, 2013) 268. See also Joshua Dubler and Vincent Lloyd, 'Mass Incarceration Is Religious (and So Is Abolition): A Provocation' Abolition (Blog Post, 18 August 2016) [3] <https://abolitionjournal.org/mass-incarceration-is-religious-and-so-isabolition/>.

33 Senanayake and Ferson (n 28) 574 (emphasis omitted).

34 Porter and Porter (n 16) 97.

35 Ibid.

36 Porter and Porter (n 16) were writing in the midst of the most intense period of the encounter with HIV/AIDS in the UK. They describe the situation as polarised, where one group of well-meaning medical and health professionals had argued for action over inaction, that they 'too readily presumed that any action is better than none, that necessity knows no law, and that medico-scientific knowledge confers a right to power': ibid. So, too, did they observe that a second group, stretching across the political spectrum, had 'fiercely contended that the state's assumption of any compulsory powers believed to counter AIDS would form a part of a conspiratorial agenda for the creation of a police state, leading to the criminalization of illness together with all other forms of deviance': ibid. But see Bennett and Carney who advise that 'there is no antidote to the tendency for some nations to overreact ... or fail to adequately report on the reasons for special domestic measures': Belinda Bennett and Terry Carney, 'Planning for Pandemics: Lessons From the Past Decade’ (2015) 12(3) Journal of Bioethical Inquiry 419, 420. 
recent discussion in Australia regarding public health powers and their use has not been marked by hysteria, it has, thus far, taken place in a kind of vacuum, without the benefit of clear information about the actual use of coercive public health powers. Without that information regarding 'real cases', debates and discussion regarding the normative aspects of the availability and use of public health and human biosecurity powers will be difficult and will risk being both too ideal or abstract. ${ }^{37}$ To advance the conversation in the spirit of rigour, context and realism, this situation must be rectified.

To begin that task, I provide a detailed picture of prevailing state, territory and Commonwealth public health and biosecurity regimes as a way of introducing and contextualising the data relating to their use reported in Part III of this article.

\section{B Coercive Public Health and Human Biosecurity Powers}

In Australia, formal public health and biosecurity powers are exercised by local, state, territory and Commonwealth governments. ${ }^{38}$ The key sources of law are found in the variously-named public health Acts of each state and territory and the Commonwealth Biosecurity Act 2015 (Cth), and National Health Security Act 2007 (Cth). So, too, are there direct and indirect relationships between domestic law and international instruments, ${ }^{39}$ namely the International Health Regulations. ${ }^{40}$

Clarification as to the meaning of 'coercion' and 'coercive' is necessary at this point as the powers I focus upon here are those that are (most) coercive in nature. The customary approach used to identify coercion in public health activities is to review a practice or power's impact upon the exercise of choice by

37 This is a point that Angus Dawson also makes in relation to public health emergency planning and response, where he argues that a focus on 'real situations' is essential for understanding the true complexity facing a decision-maker: Angus Dawson, 'Professional, Civic, and Personal Obligations in Public Health Emergency Planning and Response' in Bruce Jennings et al (eds), Emergency Ethics: Public Health Preparedness and Response (Oxford University Press, 2016) 186.

38 There has been some literature written that accounts for these powers in Australia. See especially Cristina Pelkas, 'State Interference with Liberty: The Scope and Accountability of Australian Powers to Detain during a Pandemic' (2010) 12(1) Flinders Law Journal 41; Belinda Bennett and Terry Carney, with others, have produced a recent series of works focused particularly on the question of public health powers through the lens of federalism, Bennett, Carney and Bailey, 'Emergency Powers \& Pandemics' (n 25); Brian R Opeskin, 'The Architecture of Public Health Law Reform: Harmonisation of Law in a Federal System’ (1998) 22(2) Melbourne University Law Review 337.

39 To which the Biosecurity Act 2015 (Cth) is said to give effect.

40 World Health Organization, International Health Regulations (2005) (WHO Press, $3^{\text {rd }}$ ed, 2016). However, these international instruments and their influence on domestic lawmaking and practice are not the focus here. As to the role of international instruments, especially the International Health Regulations, an appropriately circumspect interpretation of the nature and influence of those international legal materials should be taken up when they are addressed to avoid an overinvestment in their instrumental potential. See, eg, this dynamic at work in the response by Kamradt-Scott to an earlier article by Wernli et al: Adam Kamradt-Scott, 'A Public Health Emergency of International Concern? Response to a Proposal to Apply the International Health Regulations to Antimicrobial Resistance' (2011) 8(4) PLoS Medicine e1001021; Didier Wernli et al, 'A Call for Action: The Application of the International Health Regulations to the Global Threat of Antimicrobial Resistance' (2011) 8(4) PLoS Med e1001022. 
individuals. ${ }^{41}$ Options available to government and policymakers are differentiated between those that 'eliminate choice,42 or 'restrict choice' at one extreme, through to those that 'provide information' or 'do nothing ... simply monitor the current situation' at the other. ${ }^{43}$ Despite multiple definitional resources, ${ }^{44}$ it may well be impossible to completely demarcate what constitutes a 'coercive public health power' and what does not. For one, all law and regulation is, in a real sense, coercive. Despite this, a core group of powers are clearly highly coercive, and include the power to compel a person to undergo medical testing or treatment, to compel particular persons to engage in or refrain from particular behaviours, and limit their free movement, including through the power to involuntarily isolate or quarantine a person or group of persons. ${ }^{45}$ It is these 'coercive' powers that this research focuses upon.

\section{Commonwealth Biosecurity and Health Security}

The Commonwealth has traditionally held limited powers in relation to 'public health'. ${ }^{46}$ It does, however, have specific powers in relation to quarantine. ${ }^{47}$ While in the federal context the Quarantine Act 1908 (Cth) has traditionally dominated the response to public health and human biosecurity, a wholly new legislative regime consisting of the Biosecurity Act 2015 (Cth), ${ }^{48}$ the National Health Security Act 2007 (Cth) and related regulations now form the heart of the Commonwealth powers in this field. ${ }^{49}$ The regime is very new and, according to the Commonwealth Department of Health, 'a number of the powers relating to human biosecurity, including the Human Biosecurity Control power', ${ }^{50}$ are yet to be tested.

The coercive powers of the human biosecurity regime now held by the Commonwealth are broader and more detailed than those found in the earlier

Nuffield Council on Bioethics, Public Health: Ethical Issues (Report, November 2007).

42 The report describes the elimination of choice as to '[r] egulate in such a way as to entirely eliminate choice, for example through compulsory isolation of patients with infectious diseases': ibid xix, 36, 42. Ibid.

44 Lawrence O Gostin and Lindsay F Wiley, Public Health Law: Power, Duty, Restraint (University of California Press, 2016) 31; Commission on Human Rights, Siracusa Principles on the Limitation and Derogation Provisions in the International Covenant on Civil and Political Rights, UN ESCOR, $41^{\text {st }}$ sess, UN Doc E/CN.4/1985/4 (28 September 1984) annex. See Diego S Silva and Maxwell J Smith, 'Limiting Rights and Freedoms in the Context of Ebola and Other Public Health Emergencies: How the Principle of Reciprocity Can Enrich the Application of the Siracusa Principles' (2015) 17(1) Health and Human Rights Journal 52 as to recent use of the Siracusa Principles.

45 See the account of these powers below in Part III.

46 Commonwealth powers in the area were, in essence, confined to quarantine, with the quarantine power explicitly named in the Australian Constitution s 51(ix), Quarantine Act 1908 (Cth). See especially Alison Bashford, Imperial Hygiene: A Critical History of Colonialism, Nationalism and Public Health (Palgrave Macmillan, 2004) 117-23.

47 The Commonwealth holds an express power in relation to quarantine: Australian Constitution s 51(ix).

48 The Biosecurity Act 2015 (Cth) commenced on 16 June 2016.

49 See the work of Anthony Gray as to the history of Commonwealth power and activity in this area up until and including the introduction of these contemporary regimes: Anthony Gray, 'The Australian Quarantine and Biosecurity Legislation: Constitutionality and Critique' (2015) 22(4) Journal of Law and Medicine 788.

50 Email from Department of Health (Cth) to David Carter, 11 September 2017, [3]. 
Quarantine Act 1908 (Cth). The Biosecurity Act 2015 (Cth) $)^{51}$ allows a 'human biosecurity control order' (a newly created instrument) to be imposed on an individual if that individual may have a listed human disease. ${ }^{52}$ Using these instruments, the Commonwealth activates and imposes public health and human biosecurity measures upon individuals who are thought to, or in fact do, carry a listed human disease, ${ }^{53}$ upon those within a defined geographic area, or during an emergency. ${ }^{54}$

In the Commonwealth regime, a variety of measures ('biosecurity measures' $)^{55}$ may be included in a human biosecurity control order. These include an obligation to provide contact information for any individual to whom the person subject to the order has been, or will be, in close proximity ('managing contacts'), ${ }^{56}$ to advise of their health status ('contacting officer with health status'), ${ }^{57}$ to maintain isolation at their place of residence, not visit specified places, classes of place or come in close proximity with a specific class of individuals ('restricting behaviour'), ${ }^{58}$ to wear specific clothing or equipment ('risk minimisation interventions'), ${ }^{59}$ to be decontaminated,${ }^{60}$ to undergo medical examination and diagnostic testing, ${ }^{61}$ to be vaccinated and treated, and to take medication or be isolated at a specified medical facility. ${ }^{62}$

The test applied for imposing such a biosecurity measure is not onerous. The relevant officer must be satisfied that exercise of the biosecurity measures 'contributes to managing the risk of ... contagion of a listed human disease ${ }^{63}$ or, more broadly, of 'a listed human disease entering, or emerging, establishing itself or spreading in, Australian territory or a part of Australian territory'. ${ }^{64}$ Once issued, a human biosecurity control order may be enforced by the giving of a direction that requires compliance with a human biosecurity control order. ${ }^{65}$ The investigation of potential or actual non-compliance with a human biosecurity control order may be followed by enforcement of the order through means such as civil penalties, infringement notices, enforceable undertakings and injunctions, as well as the exercising of various powers with or without a warrant or

51 The Biosecurity Act 2015 (Cth) is jointly administered by the Department of Health and Department of Agriculture and Water Resources; however, here the focus is on those aspects of the Act that are related to human biosecurity, and that are, therefore, administered primarily by the Department of Health.

52 Biosecurity Act 2015 (Cth) s 60.

53 National Health Security (National Notifiable Disease List) Instrument 2018 (Cth), pursuant to National Health Security Act 2007 (Cth) s 11.

54 See especially Biosecurity Act 2015 (Cth) ss 60-74. For geographic zones, named 'biosecurity activity zones', see Biosecurity Act 2015 (Cth) s 395.

55 Ibid s 82 .

56 Ibid s 85 .

57 Ibid s 86.

58 Ibid s 87.

59 Ibid s 88.

$60 \quad$ Ibid s 89.

61 Ibid ss $90-1$.

62 Ibid s 97.

63 Ibid s 84(a).

64 Ibid s 84(b).

65 Given by the Director of Human Biosecurity: ibid s 72. 
consent. ${ }^{66}$ Force may be used to prevent a traveller leaving Australian territory or to detain a person who fails to comply with an isolation measure. ${ }^{67}$

\section{The Public Health Acts}

State and territory public health law is expressed primarily in the variously named public health Acts ('the public health Acts') ${ }^{68}$ In the Australian context, the public health Acts have been at the centre of public health activity, tracing their lineage in many instances to colonial legislation. ${ }^{69}$

The powers available to authorised persons through the public health Acts are both extensive and highly elastic. As to their extensive nature, prevention and control powers in the public health Acts include the power to compel individuals in a broad range of ways. This includes the power to compel a person to provide information, including documents, ('providing information or documents'), ${ }^{70}$ refrain from specified conduct ('restricting behaviour'), ${ }^{71}$ refrain from visiting a specific place or specific class of place, ${ }^{72}$ undergo medical examination and diagnostic testing, ${ }^{73}$ undergo specified treatment, ${ }^{74}$ including counselling, ${ }^{75}$ submit to the supervision of one or more persons or a specified class of persons, ${ }^{76}$ and be detained and/or isolated at a specified medical facility or other place. ${ }^{77}$

As to their 'elasticity', all public health Acts grant very wide discretion to the relevant decision-maker, and many provide few - if any - real limits to what may be imposed upon an individual, at least within the text of the legislative instrument itself. By way of example, the NSW provisions list four (albeit broad)

66 Found principally in ch 9 of the Biosecurity Act 2015 (Cth): ibid ss 480-538.

67 Ibid s 95. Force may not be used against an individual to comply with most of the biosecurity measures that may be imposed. However, force may be used in preventing an individual leaving Australian territory in contravention of a traveller movement measure (see s 101) or in detaining a person who fails to comply with an isolation measure (see s 104). But see in relation to the use of force ibid ss 104,400 , $505,515$.

68 Public Health Act 1997 (ACT); Public Health Act 2010 (NSW); Public and Environmental Health Act 2011 (NT); Notifiable Diseases Act 1981 (NT); Public Health Act 2005 (QLD); South Australian Public Health Act 2011 (SA); Public Health Act 1997 (Tas); Public Health and Wellbeing Act 2008 (Vic); Western Australia has recently transitioned to a new public health legal regime in that state with the commencement of the Public Health Act 2016 (WA) on 22 July 2019; the former source of law for public health activities in Western Australia was the Health (Miscellaneous Provisions) Act 1911 (WA); the transition is also supported by the Public Health (Consequential Provisions) Act 2016 (WA); (collectively 'the public health Acts').

69 See, eg, the Infectious Disease Supervision Act 1881 (NSW) established in response to the smallpox outbreak in the colony of NSW. See also Public Health Act 1876 (SA) and the Public Health Act 1875 (Vic). See also the various quarantine powers, such as that dating from 1832 in the Colony of NSW: Quarantine Act 1832 (NSW).

70 See, eg, Public Health Act 1997 (ACT) an authorised office may request (s 106(2)(c)(ii)), a person shall comply with the request (s 106(5)). See also Public Health Act 2010 (NSW) ss 110-14. See, eg, Public Health and Wellbeing Act 2008 (Vic) s 117(5)(c)-(d).

72 Ibid s 117(5)(e).

73 See, eg, Public Health Act 2010 (NSW) s 61.

74 See, eg, ibid s 62(3)(b).

75 See, eg, ibid s 62(3)(c); Public Health and Wellbeing Act 2008 (Vic) s 17(5)(a).

76 See, eg, Public Health Act 2010 (NSW) s 62(3)(d); Public Health and Wellbeing Act 2008 (Vic) s 117(5)(h).

77 See, eg, Public Health Act 2010 (NSW) s 62(4); Public Health and Wellbeing Act 2008 (Vic) s 117(5)(k). 
categories or classes of coercive power that an authorised person may impose: namely, to refrain from specified conduct, to undergo treatment, to undergo counselling, and to submit to supervision or to undergo treatment at a specified place $^{78}$ (which may include being detained at that place either while undergoing treatment, ${ }^{79}$ or for the duration of the order). ${ }^{80}$ In the Northern Territory, however, an authorised person may 'direct the person to carry out measures which the medical officer believes necessary for the treatment of, or to prevent the spread or possible spread of, the relevant notifiable disease'. ${ }^{81}$ Unlike the Public Health Act 2010 (NSW), there are no limits embedded in the Notifiable Diseases Act 1981 (NT) to guide or define what 'measures' a person may be directed to undertake or refrain from, save that the authorised medical officer believes them to be necessary. This wide ambit extends into the formation of orders made by the Chief Health Officer of the Northern Territory, where a failure to comply with an earlier notice empowers the decision-maker to make 'such order as he [sic] thinks fit'. ${ }^{82}$

Tracing the use of public health orders is crucial to understanding the (lawful) use of these coercive public health powers. Public health orders are the mechanism used to activate the most coercive aspects of these powers in Australia. They exist in some form in each Australian jurisdiction; however, the nomenclature, their availability and associated processes, and the specific ambit of their power differ, at times quite markedly.

As to nomenclature, public health orders are referred to by a variety of terms, and are structured in various ways in each jurisdiction, ${ }^{83}$ although for ease of use I simply refer to them here as 'public health orders'. The Commonwealth regime utilises 'human biosecurity orders', 'directions requiring compliance' and 'infringement notices'. NSW, Victoria and Queensland utilise 'public health orders', with Victoria also issuing examination and testing orders, Queensland issuing 'infringement notices', and the Australian Capital Territory ('ACT') issuing both 'public health directions' and 'public health orders'. The Northern Territory utilises a 'notice' to an infectious person or suspect person issued under section 11 of the Notifiable Diseases Act 1981 (NT) (known colloquially as a 'Section 11 Notice') and 'orders' (known colloquially as a 'Section 13 Order') issued under section 13 of the same Act. ${ }^{84}$ South Australia provides that the Chief Public Health Officer or their delegate may 'give such directions and take

Public Health Act 2010 (NSW) s 62(3).

For 'Category 4' conditions, currently limited to avian influenza in humans, Middle East respiratory syndrome coronavirus, Severe Acute Respiratory Syndrome (SARS), Tuberculosis (TB), Typhoid, Viral haemorrhagic fevers (such as Ebola): ibid sch 1.

For 'Category 5' conditions, currently limited to Human Immunodeficiency Virus (HIV) infection: ibid. Notifiable Diseases Act 1981 (NT) s 11.

Ibid s 13. Note that s 13(2) provides a list of potential orders, however, such orders are offered 'without limiting the generality' of the power of the Chief Health Officer to make 'such [an] order as he [sic] thinks fit'. But see guidance issued by the Director of the Centre for Disease Control of the Northern Territory: Northern Territory Government, Department of Health, 'Guidelines for the Management of People with Infectious Diseases Who Put Others at Risk of Infection' (Guidelines, 10 April 2013).

3 See Appendix A below in relation to the specific requests made of each jurisdiction. These requests express the various structures of public health orders in each jurisdiction.

Notifiable Diseases Act 1981 (NT) ss 11, 13. 
such action as may be appropriate to avert [the danger to public health from the possible spread of a notifiable condition] ${ }^{85}$ may make an 'order' to impose a requirement ${ }^{86}$ or may make an 'order' to impose a direction.

As to their availability, limits are imposed by the use of differing tests for initiating a public health order, or by the imposition of standards required to justify imposition of a particular condition. For example, in the ACT, the Chief Health Officer may make a public health direction where they have 'reasonable grounds for believing that it is necessary to prevent or alleviate a significant public health hazard ${ }^{87}$ In Victoria, a public health order may be made after meeting a series of tests which include that a reasonable attempt has been made to provide the person with information, consideration of whether 'urgent action will significantly affect the public health outcome', and whether it is necessary to make the public health order in order to eliminate or reduce the risk of the person causing a serious risk to public health. ${ }^{88}$ Common to some public health Acts are statements of principle or formal matters that either must or should be considered by an authorised person when deciding to make a public health order. In NSW, for example, the Public Health Act 2010 (NSW), compels a decision-maker to take into account the 'principle that any restriction on the liberty of a person should be imposed only if it is the most effective way to prevent any risk to public health ${ }^{89}$ and to consider whether 'options other than a public health order' are available to deal with the public health risk, while directing the decisionmaker to relevant guidelines in relation to both TB and HIV for the management of people who place others at-risk of infection. ${ }^{90}$ The situation differs in Victoria, where the measure "which is the least restrictive of the rights of the person should be chosen'. ${ }^{91}$

This diversity continues in relation to the process for issuing public health orders and punishment for breach of their terms. For example, in NSW an authorised medical practitioner may make a public health order that is itself enforceable, ${ }^{92}$ the breach of which is a criminal offence punishable by a maximum penalty of a fine of $\$ 11,000$ or imprisonment for six months. ${ }^{93}$ In the $\mathrm{ACT}$, the Chief Health Officer may issue a public health direction, ${ }^{94}$ and only

South Australian Public Health Act 2011 (SA) s 66.

Ibid ss 73-4.

Public Health Act 1997 (ACT) s 113(1).

Public Health and Wellbeing Act 2008 (Vic) s 117(1)(b), (2)(d).

Public Health Act 2010 (NSW) s 62(6)(a) (emphasis added).

Public Health Regulation 2012 (NSW) s 39(1)(b).

Public Health and Wellbeing Act 2008 (Vic) s 112 (emphasis added).

Public Health Act 2010 (NSW) s 62. In NSW, it is an 'authorised medical practitioner' who may make a public health order. This is defined at section 60 to include the Chief Health Officer of NSW or registered medical practitioners who are authorised by the Secretary of Ministry of Health for this purpose: Public Health Act 2010 (NSW) s 60.

93 Ibid ss 70-3.

94 Although the violation of the terms of a public health direction seem not to carry any penalty, uniquely amongst the public health Acts the ACT provisions note that '[a]ny costs or expenses incurred by the Territory in implementing, or attempting to implement, a public health direction under this section are a debt due to the Territory by the person to whom the direction was issued': Public Health Act 1997 (ACT) s $116(5)$. 
then may apply to a magistrate to make a public health order that a person subject to an existing direction comply with that direction or be fined for failing to comply with the direction, or impose further orders to prevent or alleviate the relevant public health hazard. ${ }^{95}$ The Northern Territory affords any authorised person the power to issue a notice to an infected person or suspect person to carry out measures that the authorised person believes necessary for the treatment or prevention of a notifiable disease. ${ }^{96}$ In NSW, it is an offence to obstruct or assault persons exercising or attempting to exercise their functions under the Public Health Act 2010 (NSW), punishable by a fine or imprisonment for up to six months, or both. ${ }^{97}$ So, too, is it an offence in South Australia, where, for example, hindering or obstructing the exercise of the Chief Public Health Officer's activities, failing to answer a question to the best of one's knowledge, information or belief or failing to provide reasonable assistance to facilitate an inspection is punishable by a much larger fine of up to $\$ 25,000$.

Knowing that there exists a nexus of coercive public health powers across the nation naturally prompts a question as to how they work in practice. This is perhaps particularly so because the power wielded by public health officials through the public health Acts represent one of the most significant sources of coercive power available to the executive. Yet, ascertaining how these powers are exercised, or accessing reviews of their use is not possible. As I discuss in the next Part of this article, no regular account or justification of their use is provided by the state and seeking that information through open government processes was not straightforward.

\section{THE USE OF COERCIVE PUBLIC HEALTH POWERS IN AUSTRALIA}

This second part of the article reports on the use of public health powers in Australia. It begins with a brief account of the data collection methods employed to collect this otherwise unreported information, including notes on the limitations of these methods. This methods statement is followed by a report of the substantive results of this research, including analysis of the active use of coercive public health powers, reports on the variation in practice between jurisdictions and, finally, a description of the lack of transparency that accompanies the use of these powers.

\section{A Methods}

The aim of this research was to seek out publicly available information on the use of these 'coercive' powers. Motivation for seeking publicly available

\footnotetext{
95 Ibid s 118.

96 Notifiable Diseases Act 1981 (NT) s 11; persons are authorised under provisions in the Public and Environmental Health Act 2011 (NT) s 76, and include the Chief Health Officer, those appointed by the Chief Health Officer as an authorised officer and others, including police officers. 
information flows from the traditions that are concerned with transparency regarding state action and that inform contemporary open government, public interest and rule of law discourses. To achieve this, a semi-structured review of public records, scholarly and 'grey' literature was complemented by direct engagement with the authority responsible for administrating public health powers in each jurisdiction. This was followed by initiating discussions or making requests for release of information relating to the use of public health powers by administrative action. The concern with publicly available information means that this excluded requests or processes that utilised researcher-only or research pathways, rather than those available to the general public. ${ }^{98}$

In some jurisdictions direct engagement methods facilitated release of information through administrative action. In others it led to either advice or agreement to submit a FOI request in order to facilitate release of information through processes established for those purposes. Some jurisdictions indicated an unwillingness or inability to release information either by administrative action or FOI processes. In those instances, a FOI request was made unilaterally. These processes and their results are described for each jurisdiction in Appendix A.

There was a marked diversity of attitude toward the request. Some jurisdictions explicitly, and others implicitly, expressed an openness or even willingness to formulate a response and release of information. Others were more cautious. At one extreme, some explicitly registered their strong opposition to the request being made at all, often in the strongest terms. Others indicated that they would not release information - in one instance even prejudging a potential FOI request with a pre-emptive refusal. In another instance, the jurisdiction directly communicated that it would be seeking legal advice on the matter as part of advising of its refusal to release information by administrative action. Where a jurisdiction indicated an unwillingness to release information, core themes in their reasons were confidentiality, the potential for reidentification of the data, that release would risk the cooperation the state receives from an unspecified range of people, and that the issuing of public health orders was a legal process that was highly personal and confronting for individuals involved.

The results of these processes of direct engagement and FOI request led to the release of a set of documents for each jurisdiction. ${ }^{99}$ These documents varied both in terms of their nature (eg, copies of emails, ministerial briefings, public health orders) and structure. Given that the aim of this research was to understand the use of public health powers - with a focus particularly on public health orders - a data extraction form was utilised to undertake a structured extraction process focusing on data relating to the use of powers expressed in documents. This form and its results are available as an online appendix to this

98 Given the status of requests as arising from a researcher and governed by research ethics systems, there is no way of knowing exactly what influence this had on the release of information.

99 These documents are held on file by the author. However, they are also available as a research dataset. Access is subject to research governance processes. See David Carter, 'Australian Public Health Orders Issued by Australian State and Territory Governments: Dataset 2004-2017' University of Technology Sydney (26 September 2019) <http://doi.org/10.26195/5d8c388f6e9dc> ('Australian Public Health Order Dataset'). 
article which includes extensive notes on the data to aid interpretation. ${ }^{100}$ The data extracted included the date of order, nature and requirements of the order, public health risk addressed by the order, duration of the order, and actions or enforcement actions taken.

\section{B The Use of Coercive Public Health Powers in Australia}

It is clear that the use of coercive public health and biosecurity powers in Australia occurs but is not currently accompanied by sufficient transparency or public accountability to facilitate a systematic monitoring or assessment of their use. The following table summarises the methods employed and which jurisdictions made a release of information.

Table 1: Summary of Research Method and Results

\begin{tabular}{|l|l|l|l|l|l|}
\hline \multirow{2}{*}{ Jurisdiction } & \multicolumn{2}{l}{ Method Attempted } & \multicolumn{2}{l|}{ Release } \\
\cline { 2 - 6 } & $\begin{array}{l}\text { Public } \\
\text { Records }\end{array}$ & $\begin{array}{l}\text { Administrative } \\
\text { Action }\end{array}$ & FOI & $\begin{array}{l}\text { Released } \\
\text { Documents }\end{array}$ & $\begin{array}{l}\text { Created New } \\
\text { Document }\end{array}$ \\
\hline NSW & $\checkmark$ & $\checkmark$ & & $\times$ & $\checkmark$ \\
\hline QLD & $\checkmark$ & $\checkmark$ & $\checkmark$ & $\checkmark$ & $\times$ \\
\hline SA & $\checkmark$ & $\checkmark$ & $\checkmark$ & $\times$ & $\times$ \\
\hline Tas & $\checkmark$ & $\checkmark$ & $\checkmark$ & $\times$ & $\checkmark$ \\
\hline Vic & $\checkmark$ & $\checkmark$ & $\checkmark$ & $\times$ & $\times$ \\
\hline WA & $\checkmark$ & $\checkmark$ & $\checkmark$ & $\checkmark$ & $\checkmark$ \\
\hline ACT & $\checkmark$ & $\checkmark$ & $\checkmark$ & $\times$ & $\checkmark$ \\
\hline NT & $\checkmark$ & $\checkmark$ & $\checkmark$ & $\checkmark$ & $?$ \\
\hline
\end{tabular}

In response to the suite of methods described above, the Commonwealth, NSW and the ACT released information by various means. Queensland, perhaps because of its devolved and decentralised public health enforcement system, released some information after a period of time. The Northern Territory was initially cooperative, and then, highly combative as to the request, however, like Tasmania released some information in due course. Western Australia was more resistant to requests, allowing years to elapse before completing a release of

100 David J Carter, 'Online Electronic Appendix: The Use of Coercive Public Health Powers in Australia' Open Science Foundation, (Data Repository, 2 September 2019) <https://doi.org/10.17605/OSF.IO /KQR6E> ('Online Electronic Appendix'). 
information. Finally, South Australia and Victoria completely refused any requests, formal or otherwise. South Australia still with an outstanding and unprocessed FOI request successfully lodged in May 2017.

Analysis of these new data produces three key findings. First, in an era in which public health discourse is often focused upon non-communicable diseases and the social determinants of health, there is inadequate attention paid to public health's legal instantiation and coercive practices of communicable diseases control which are actively used. Secondly, there exists significant variation in practice between jurisdictions, which has received little by way of critical commentary or analysis. And, finally, there is an almost complete lack of publicly available information and reporting on the objectives, outcomes, processes and procedures of the use of coercive public health and human biosecurity powers by the state. I conclude that this lack of publicly available information must be rebalanced in light of the strong public interest arguments for transparency and accountability and in response to the cases outlined below that show lengthy periods of detention and subjection to public health orders for particular individuals, seemingly without the accountability of public reporting or other scrutiny. I deal with each of these claims in turn.

\section{The Active Use of Coercive Powers}

The first finding is that coercive public health and human biosecurity powers are actively used. However, from the data released, they are not frequently used at least in comparison with, for example, similar mental health processes. This is a significant finding for, at present, there exists no adequate public record administrative, scholarly or otherwise - of the use of these powers. Their use is, almost wholly unknown and unremarked. Given this state of affairs, the data collected by the FOI and open government processes as presented here provides the best available picture of the use of coercive public health powers (as reported) across each Australian state and territory. ${ }^{101}$

The data reported here are largely forms of public health orders, although warrants for arrest or detention of individuals, alongside other 'enforcement measures', are also included as instances of the use of coercive public health powers. Table 2 summarises each exercise of a coercive public health power during the period that was collected or reported, noting the scope and limitation of data as between jurisdictions.

101 There are accounts of their use in other national jurisdictions: see, eg, Amber Arnold, Graham Bickler and Thomas Stephen Harrison, 'The First 5 Years of Part 2A Orders: The Use of Powers from Court Applications to Protect Public Health in England 2010-15' (2018) 41(1) Journal of Public Health 27. 
Table 2: Public Health Orders and Enforcement Actions (as Reported) ${ }^{102}$

\begin{tabular}{|c|c|c|c|c|c|c|c|c|c|}
\hline \multirow{3}{*}{ Year } & \multicolumn{9}{|c|}{ Jurisdiction } \\
\hline & \multirow{2}{*}{ NSW } & \multicolumn{2}{|l|}{ QLD } & \multirow[b]{2}{*}{ SA } & \multirow[b]{2}{*}{ Tas } & \multirow[b]{2}{*}{$\operatorname{Vic}^{103}$} & \multirow[b]{2}{*}{ WA } & \multirow[b]{2}{*}{ ACT } & \multirow[b]{2}{*}{ NT } \\
\hline & & $\begin{array}{l}\text { Environ. } \\
\text { Health }\end{array}$ & $\begin{array}{l}\text { Notifiable } \\
\text { Conditions }\end{array}$ & & & & & & \\
\hline 2004 & 4 & & & $\begin{array}{l}z \\
\text { zo } \\
\text { ㅁํ }\end{array}$ & & $1^{104}$ & & & 1 \\
\hline 2005 & $2^{105}$ & & & 要 & & & 2 & 1 & 1 \\
\hline 2006 & & & & 뀨 & & & & & 1 \\
\hline 2007 & & & & 言 & 5 & & & 1 & 1 \\
\hline 2008 & & 3 & & & 2 & & 3 & 1 & \\
\hline 2009 & 4 & 5 & 2 & & 1 & $1^{106}$ & & & \\
\hline 2010 & 4 & 6 & 1 & & 2 & 5 & & & \\
\hline
\end{tabular}

102 Following the pattern established above, 'public health orders' here include all manner of public health direction, notice or other order made by the relevant authority. Table cells that are left blank denote years that were within the scope of the request or disclosure made by the jurisdiction, but for which where no data were reported. Where data were reported that no public health orders were made, this is recorded with a ' 0 ' in the relevant cell. Table cells that are 'greyed out' are years that were not within the scope of the request made or the disclosure provided.

103 The Victorian Department of Health and Human Services has provided a summary of public health actions in a tabular form in its Annual Report since 2009-10. FOI requests made to the Department were denied; see below for discussion. These data for Victoria are reported by Financial Year; in this table the data for each financial year are labelled by the calendar year in which the financial year ended. For example, data for 2009-10 are presented here as 2010.

104 Reported by the Department of Health of the Government of Western Australia, the 'State of Victoria spent around $\$ 600,000$ per year in providing 24-hour supervised isolation for a single HIV-infected male who was thought to represent an ongoing risk to the community (now deceased)': Executive Director, Population Health, 'The Current Short Term Isolation of a HIV-Positive Person and Options for the Long Term Isolation of Recalcitrant HIV Infected Persons Who Repeatedly Put Others at Risk of Infection' (Ministerial Briefing No 4-55597, Department of Health, Government of Western Australia, 31 March 2005) 3 (copy on file with author) ('WA Ministerial Briefing, Isolation of HIV-Positive Persons'); Australian Public Health Order Dataset (n 99).

105 Orders issued during 2004 and 2005 were described in the release of information made by NSW as applying to persons prior to 2004 (the earliest year of the request's scope) and as being made six-monthly until the death of the two persons to whom they applied, one in 2004, the other in 2005. It is here assumed that the two six-monthly orders were made relating to each person in each year they were alive.

106 There was at least one public health order issued in Victoria during the financial year 2009-10. Although the Annual Report of the Department of Human Services (as it then was) does not provide the tabular summary present in reports following 2010-11, the report provides a vignette titled 'Complex Lives Call for Creative Solutions' where an injecting drug user diagnosed with TB is made subject to a public health order following an absconding from treatment. See Victorian Government, Department of Human Services, Annual Report 2008-09 (Report, October 2009) <http://www.health.vic.gov.au/doh/downloads/ Annual-Report-2008-09-Full.pdf> 7. 


\begin{tabular}{|c|c|c|c|c|c|c|c|c|}
\hline 2011 & & 2 & & 0 & 4 & & 1 & 3 \\
\hline 2012 & 2 & 2 & & 4 & 6 & 5 & & 1 \\
\hline 2013 & & 11 & & 0 & 4 & & & 1 \\
\hline 2014 & & 13 & & 0 & 2 & & & \\
\hline 2015 & & 13 & 4 & 0 & 3 & & & 1 \\
\hline 2016 & & & & 1 & 3 & 3 & & 1 \\
\hline $2017^{107}$ & & & & & & & & \\
\hline
\end{tabular}

This summary of the use of coercive public health powers was reconstructed from the various documents, emails, memoranda and tabular information provided by each jurisdiction. It is important to note that these reported and collected instances of the use of coercive public health powers do not represent a complete record of the use of these powers. Multiple jurisdictions made explicit reference to the incomplete or partial nature of their disclosure and, at present, South Australia has chosen to withhold all information regarding the use of these powers. ${ }^{108}$ Moreover, the results presented here likely include cases already on the public record. For example, the case of Sharleen Spiteri is likely to be related to at least two orders reported by NSW as being made in $2004-05^{\prime} ;{ }^{109}$ however, this is not made explicit in the disclosure. On the other hand, orders related to the well-known Victorian case of Lam Kuoth are likely not reported by the State of Victoria in its Annual Reports from which the data reported is taken. Kuoth was subject to 18 months of successive 28-day orders from April 2007 onwards. Reporting in Victorian Annual Reports begins in 2009-10, after this first tranche of orders had been made. ${ }^{110}$ Reporting made by Queensland includes orders made

107 While some requests included 2017 within their scope, generally as being 'from 2004 onwards', data collection concluded part way through 2017 , so data for 2017 is partial.

108 While South Australia refused to provide any data, other states and territories noted the potential or actual incompleteness of their disclosures. Generally speaking, no jurisdiction was able to provide confirmation that their disclosure was 'complete' in any sense of the word. Moreover, NSW noted that the disclosure was based on a brief data collection exercise undertaken for the purposes of the request, Western Australia excluded material that might be subject to legal privilege, Queensland noted explicitly that the MAPLE system used by the Department of Health came into operation in recent years, in order to establish 'regulatory compliance' that had been lacking up until that point in time, and that at present not all Health and Hospital Services utilised the system (and even then, those who did utilise the system did not necessary do so completely).

109 Spiteri died in 2005, and NSW references orders at that time that continued until the person was deceased: 'Shutting Down Sharleen' (n 1).

110 It is unclear/unknown whether Kuoth was made subject to further orders following those narrated by the Court in his criminal trial and appeal. However, at trial, it was noted that following the 18 months of orders narrated by the Judge, '[t] he Chief Health Officer will continue to make orders relating to you ... until such time as the need for the use of such power no longer exists': Kuoth, Lam v R [2010] VSCA 103, [6] (Maxwell P). 
under public health law in relation to environmental hazards (eg, unsecured asbestos) that I have separated into a separate column. What the table also is unable to show is how many orders relate to the same person. To reduce the risk of double-counting or otherwise distorting the results, I have chosen not to add orders to the table known from the public record to have been made - such as those relating to Kuoth - relying instead on the sources provided by each jurisdiction. ${ }^{111}$ This reduces the risk of double-counting and maintains the focus on the official public reporting or disclosure of the use of these powers.

As to the 'focus' of the orders reported here, during the period studied, coercive public health powers were largely directed at those either living with HIV or TB, or being suspected of the same. The application of public health powers as between these two conditions is quite different in each jurisdiction, where ascertainable from the records disclosed. For example, in NSW nine orders were reported to have been issued in relation to the treatment of TB, and approximately five in relation to HIV. ${ }^{12}$ Whilst HIV and TB feature prominently in the use of public health powers, these are not the only conditions to which they are applied. In the ACT, for example, three orders related to HIV and one to another influenza, while in Western Australia it is clear that six orders related to HIV, while the remaining seven related simply to what was described as 'a venereal disease'. ${ }^{113}$ In relation to South Australia, Tasmania, Queensland and Victoria, distinguishing powers directed at particular conditions is not possible on the basis of the data available.

TB and HIV are conditions that are common targets for the use of public health orders for at least three reasons. The first is that they are communicable diseases that are recognised as representing a public health risk within the public health Acts and their associated regulations. ${ }^{114}$ The second is that these conditions are present in the Australian community - as opposed to other conditions that, whilst representing a public health risk, are not currently present in the community (eg, SARS or Ebola, both of which are listed as conditions regarding which a public health order may be issued). Finally, public health orders are suitable responses to these conditions that are transmitted by way of various forms of contact or proximity, and so public health orders that modify risk-related behaviours (ie, impose safer sex conditions or prevent attendance at sex-on-premises venues, or require the wearing of a mask) or impose isolation

111 See generally Carter, 'HIV Transmission' (n 8).

112 NSW specifically engaged with relevant decision-makers at the local health district/hospital level. It seems that, like Queensland, decisions relating to the use of public health powers directed to those suspected of or having a confirmed diagnosis of TB are undertaken at the local level, and those in relation to HIV at the departmental level or within a state-wide public health HIV unit. This may influence the results in NSW and other jurisdictions, where different approaches to data collection or the scope of FOI searches will have influenced the 'coverage' of those local decisions related to TB.

113 No doubt reflecting the name of the regulations under which orders were issued at that time. Further particulars were redacted by decision-makers.

114 See, eg, the inclusion of Tuberculosis and HIV as diseases on the National Notifiable Disease List: National Health Security (National Notifiable Disease List) Instrument 2018 (Cth), pursuant to National Health Security Act 2007 (Cth) s 11. 
are effective at preventing the onward transmission of a condition like TB or HIV.

Beyond the question of the raw number of orders, or the conditions targeted, a very important aspect of these orders relates to the nature or character of the order. Recalling the discussion above, one way of framing this inquiry was to ascertain whether the cases of Spiteri or Kuoth were dramatic outliers or something closer to 'business as usual' for practice in this domain. To answer that question, further analysis is required as to what actions were authorised by way of the orders.

There are two main classes of order-making: the first, where orders are used to detain persons, often for very lengthy periods of time, and often by use of 'serial' order-making; the second, where orders are used to maintain treatment and testing regimes across time. I deal with each class of order in turn followed by a brief reflection on 'serial order-making', a practice that is used in relation to both detention and testing and treatment regimes.

\section{(a) Detention Regimes}

The first class of orders are used to maintain the detention of a particular individual. Importantly, this includes, in some cases, indefinite detention. Orders have directed persons to undergo formal isolation. So, too, have they authorised the arrest/removal of persons and directed that police or others convey persons into the custody of a hospital or, in one case, a police lockup, to undergo isolation. ${ }^{115}$ Finally, orders have also been issued for the arrest and return of persons who have absconded from isolation. The majority of the orders reported here enforce various forms of such practice, and orders for arrest and detention feature in the records disclosed by every jurisdiction apart from the ACT (and potentially Tasmania, where data is not sufficiently clear to confirm this, or South Australia, where no data was provided).

Where time limits for detention or isolation are either stipulated or ascertainable on the records released, periods of detention range from the shortest period reported of 17 days in Queensland, through periods of discretionary detention ("until a medical officer authorises their release on the grounds that the person is not an infected person or is no longer a suspect person') ${ }^{116}$ to instances of indefinite detention used in NSW, Victoria and possibly Western Australia.

Indefinite detention was known in the literature to have occurred once in NSW and once in Victoria, in relation to the cases of Sharleen Spiteri and Lam Kuoth respectively. However, this research reveals that multiple cases of extended or indefinite detention have occurred in a number of jurisdictions on many more occasions. For example, in Western Australia, a person described as

115 See Online Electronic Appendix (n 100) 13 for further detail of this order made by the State of Western Australia on 13 April 2005.

116 As is language used in the case of the Northern Territory: see ibid 25. This is also the case in other jurisdictions, see, eg, the ACT and their use of orders without end date or specific/specified duration: ibid 20-2. Interested parties may also consult the Australian Public Health Order Dataset (n 99) which holds copies of original documents that are described or from which quoted material is extracted in the Online Electronic Appendix. 
living with HIV, with a 'history of alcohol abuse', ${ }^{117}$ previous isolation orders and a 'very low intellectual and very poor decision making' 118 ability, is also described as demonstrating 'reasonable compliance"119 with daily directly observed therapy leading to maintenance of a 'low' HIV viral load. ${ }^{120}$ Yet, this reasonable compliance and good clinical outcome seems to have led to detention. The person was detained for an initial period of four weeks as a measure to provide time to organise what was termed a 'long term solution' involving supervised accommodation and, it seems, an order to enforce such supervision on an ongoing/indefinite basis. A second instance in Western Australia describes at least two persons who have undergone multiple periods of detention across a decade, while canvassing potential methods for enacting 'long term isolation'. ${ }^{121}$ In this document, the Department of Health canvasses options including incarceration in a prison facility, secure mental health facility or by application of criminal law. At one point, the Department of Health reported that they had undertaken three years of engagement with the Department of Justice and Crown Solicitor, complaining that Western Australian prison officials had refused to forcibly and indefinitely detain persons on behalf of the Health Department in a Western Australian gaol due to 'legal and practical impediments', namely, as the person concerned is 'not a prisoner'. ${ }^{122}$ The Department of Health recommended to the Western Australian Minister that reform be made so that persons detained under public health powers be held in a prison facility as a prisoner. ${ }^{123} \mathrm{In}$ response, the Department of Health recommended to the Western Australian Health Minister that law reform be undertaken, so that persons detained under public health powers be reclassified as 'prisoners', thus facilitating their being held in a gaol. ${ }^{124}$ In addition to this reclassification strategy, the Department of Health also advised the Minister that a new criminal offence of 'knowingly putting others at risk of a dangerous infectious disease ${ }^{125}$ be created in Western Australia. These recommendations were made after the Department engaged in an extended account of how they have attempted to facilitate and encourage the criminal prosecution of one person living with HIV for grievous bodily harm as one way of enacting long term isolation, thereby engaging with police by providing evidence and attempting to actively advance the prosecution. The public health literature on HIV and the criminal law is almost universally opposed to criminal law being a suitable or effective response to HIV

117 Director, Communicable Disease Control Branch, 'Recommendation for Isolation Order' (Internal Memorandum, Public Health Division of the Communicable Disease Control Directorate, Department of Health, Government of Western Australia, 30 September 2008) 1 (copy on file with author) ('Recommendation for Isolation Order, WA Department of Health'); Australian Public Health Order Dataset (n 99).

118 Recommendation for Isolation Order, WA Department of Health (n 117).

119 Ibid.

120 A common measure of successful treatment of HIV.

121 WA Ministerial Briefing, Isolation of HIV-Positive Persons (n 104) (copy on file with author); Australian Public Health Order Dataset (n 99).

122 WA Ministerial Briefing, Isolation of HIV-Positive Persons (n 104) (copy on file with author).

123 Ibid 5 .

124 Ibid.

125 Ibid 4. 
transmission-related scenarios. ${ }^{126}$ And yet, the Western Australian Department of Health's own population health operation here engage in active efforts to have a person prosecuted for an HIV-related criminal offence, and for an expansion of Western Australian criminal law into the highly controversial area of endangerment.

So, too, does a Western Australian document disclose a case of indefinite/prolonged detention in Victoria where, at some point prior to March 2005 , the '[s]tate of Victoria spent around $\$ 600,000$ per year in providing 24 hour supervised isolation for a single HIV-infected male who was thought to represent an ongoing risk to the community (now deceased)' ${ }^{127}$ Similarly, an asyet-unknown case of extended/indefinite detention in NSW is now revealed by this research. In that case, the person concerned was placed under successive orders of six months' duration - that included detention - until their death. As with Sharleen Spiteri, their detention was described by the Department as facilitated by public health orders that were 'reissued with [the] person['s] consent'. ${ }^{128}$

These cases are joined by a third person living with HIV in Western Australia in 2005 (Figure 1). ${ }^{129}$

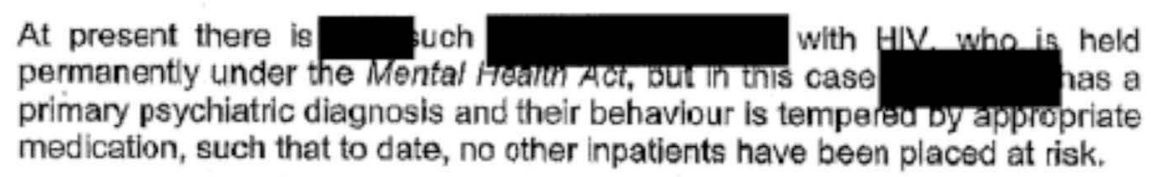

Figure 1: Description of a person living with HIV held in indefinite 'permanent' detention in Western Australia.

I draw this second case into the narrative not because the power used is one found in public health law. In this case it is not, although clearly such powers were 'at the ready' should the person be released. Rather, I do so to highlight how there is a deep relationship between public health coercive powers and those found in other areas of state coercion like mental health involuntary detention regimes. This includes at least some tactical selection and deployment of regimes to achieve the intended end of isolating persons by use of detention - including to achieve 'long-term' isolation. Given that Western Australian public health powers were, according to the decision-makers' own reports, unable to affect the detention of the first case recounted here, this tactical slippage between these powers could speak to a potentially legitimate need for reform. However, it also may speak to a more troubling form of 'venue shopping' by the executive, used to circumvent protections for those who do not present a public health risk by utilising a different power to satisfy the desire of the executive to detain them.

126 See above $\mathrm{n} 12$.

127 WA Ministerial Briefing, Isolation of HIV-Positive Persons (n 104) 3 [2].

128 See Online Electronic Appendix (n 100) 2-4, Table 1 'New South Wales, Public Health Orders 2004 2014'.

129 WA Ministerial Briefing, Isolation of HIV-Positive Persons (n 104) 3. 


\section{(b) Testing and Treatment Regimes}

The second class of order is used to maintain testing and treatment regimes, often across extended periods. The restrictions of liberty created by the application of public health powers in this way represents no less serious a curtailment of autonomy, bodily integrity and freedom of movement than in many cases involving detention. For instance, the disclosures reported here reveal orders that prevent a person from leaving the jurisdiction - indefinitely, in at least one ACT case orders to refrain from undertaking various activities, including engaging in particular forms of work (namely, in legal sex work) - and orders to submit to treatment and testing decisions made by others, including indefinite submission to the testing and treatment directions made by medical practitioners delegated with this power.

The delegation of testing and treatment is common, and no doubt practical; however, it is also often accompanied by the granting of extensive discretion to medical practitioners so nominated. For example, in the Northern Territory orders are commonly made that direct a person to undertake isolation and all testing and treatment their treating practitioner deems necessary. In at least one case, this direction was not limited to testing or treatment in relation to their primary diagnosis of $\mathrm{TB}$, the condition that justified the use of the power. ${ }^{130}$

So, too, are far longer/more extensive treatment and/or behavioural plans enforced by use of these coercive powers. In the ACT, for example, one order required the subject to 'seek medical treatment and counselling from a prescribed medical centre immediately and to follow the treatment plan that has been put in place' and ' $[\mathrm{t}] \mathrm{o}$ remain in the ACT while the treatment plan is in place', ${ }^{131}$ while another required the person to attend a 'prescribed medical centre'132 at least once every three months. When questioned as to when and how many orders remained in force in the $\mathrm{ACT}$, the jurisdiction responded that they 'have no record that the order was ever lifted and there was no time frame placed on them originally. So the order is technically ongoing in the absence of information to suggest otherwise. ${ }^{, 133}$ By 2019, these orders made by the ACT have been in force for 14 years and eight years respectively. ${ }^{134}$

130 Online Electronic Appendix (n 100) 25: see 'Northern Territory' where in 'Notes on the Data' reference is made to a Section 11 Notice, where a person with TB is directed to remain at Royal Darwin Hospital 'until your treating doctor advises that you are no longer infectious to others'; and that the person 'follow the directions of the staff at Royal Darwin Hospital and submit to all treatments and investigations required by them'. This seems to be the most broadly drafted notice/order in the documents provided. It does not restrict the direction to submit to treatments, investigations and directions to those related to or necessary for the treatment of TB.

131 Letter from Conrad Barr, Executive Director Health Protection Service to David J Carter, 12 July 2017 (copy on file with author); Australian Public Health Order Dataset (n 99). See order issued in 2005: Online Electronic Appendix (n 100) 20.

132 See order issued in 2011: Online Electronic Appendix (n 100) 22.

133 Email from ACT Government, ACT Health, Freedom of Information Coordinator to David Carter, 21 July 2017, [2].

134 Barr (n 131). 


\section{(c) Serial Order-Making}

Many of the detention and testing and treatment regimes discussed here are brought about by use of what I term 'serial order-making'. This process occurs in two ways: firstly, with the same or similar order being made repeatedly across time, and secondly, with orders of a different type being made at the one instance in time.

In relation to the first form of serial order-making, this is used in a range of jurisdictions. For example, in NSW, multiple orders are made of 28-days duration and are applied to the same patient in a serial manner. ${ }^{135}$ The order duration is no doubt influenced by the 28-day maximum time limit imposed by the Public Health Act 2010 (NSW) on orders based on a Category 4 condition like TB. ${ }^{136}$ However, whilst such orders may extend only to 28 -days duration, the active treatment of TB exceeds this period of time, and so detention of some patients with TB may also need to be extended. There are provisions in the Public Health Act 2010 (NSW) for the NSW Civil and Administrative Tribunal ('NCAT') to confirm, ${ }^{137}$ continue, ${ }^{138}$ or to review orders including extending the order beyond the 28 -day limit. ${ }^{139}$ However, in the case of Category 4 conditions like TB, an alternative approach available to the state is simply to issue a new public health order, avoiding the need to seek an extension of the order by NCAT, save for an administrative review initiated by the person subject to the order. ${ }^{140}$ This approach was taken in relation to 'Patient 2 ' in NSW, with the state issuing four orders, prior to seeking that the fourth order be continued. ${ }^{141}$

Finally, there are important considerations that lie somewhere between record keeping, process and procedure in relation to the maintenance of public health coercive control over a subject across time. In at least one jurisdiction, Western Australian public health authorities released documents that demonstrate at least two instances of 'serial order-making'. This includes the issuing or making of three orders in relation to one person on a single day as a 'just in case' strategy: one ordering isolation, one a warrant to apprehend the person for having 'not gone into the place of isolation', and one a further warrant to apprehend the person for having 'escaped' from the place of isolation. ${ }^{142}$ In practical terms, this means that a person will have had an order made (or at least purported to have been made) that authorises and orders them to present for isolation in a facility and on the same day a second warrant issued for their apprehension and conveyance to the location of their isolation on the basis that they were 'ordered

135 Specifically, five orders specify 28 days duration. A further order specifies 21 days. These of a total of nine data points reported by the jurisdiction.

136 Public Health Act 2010 (NSW) s 62(2)(d)(ii), cf s 63(2) which imposes a maximum period of three business days on an order based upon a Category 5 condition (namely, HIV), unless confirmed/extended by the NSW Civil and Administrative Tribunal.

137 Ibid s 64.

138 Ibid s 65.

139 Ibid s 65(3).

140 Ibid s 66.

141 See Online Electronic Appendix (n 100). See also Chief Health Officer, New South Wales Department of Health $v$ TC [2010] NSWADT 88.

142 Recommendation for Isolation Order, WA Department of Health (n 117). 
to be isolated' and '[have] not gone into isolation' joined by a third warrant issued for the re-apprehension following escape from isolation. These orders/warrants for their apprehension were made whilst they had not yet been informed of their initial isolation order. They are made pre-emptively, as the person subject to the order could not yet have failed to present or abscond, given that these orders were made simultaneously with the order to present for isolation. In a second instance of serial order-making, an order for isolation is signed with a warrant made for the apprehension by police of the person for having 'not gone into isolation'. This warrant is signed, however is left blank regarding the 'date of issue'. ${ }^{143}$ This seems on its face to represent the potential for a violation of some of the most fundamental tenants of the rule of law and due process and represents a form of 'pre-emptive' warrant for the arrest and detention of individuals.

\section{Variation between Jurisdictions}

These data make clear that there exists significant variation in practice between jurisdictions. This includes both variations between legal and regulatory schemes, and - the focus of this article - between rates of use of coercive powers. ${ }^{144}$

Some jurisdictions report a regular and consistent use of these powers, while others report less frequent or more irregular use. The reported rates of use of powers vary markedly both across time and between jurisdictions. Due to the material differences in population size between jurisdictions, raw numbers require contextualisation. Table 3 provides one contextualisation, where orders are expressed as a rate per 100,000 population of each state or territory. Once calculated, comparison can be made more easily and reliably. Tasmania - a jurisdiction with one of the smallest populations - utilises the powers far more frequently than NSW, the jurisdiction with the largest population (see Table 2). This variation is important not simply because of more frequent use of the powers compared to population size, but also because of the significantly larger 'at-risk' populations for both HIV and TB present in NSW than compared with Tasmania.

143 Executive Director, Public Health and Scientific Support Services, 'Warrant to Apprehend under Section 253 of the Act' (Warrant, Department of Health, Government of Western Australia, Undated) 1 (copy on file with author); Australian Public Health Order Dataset (n 99).

144 See Bennett, Carney and Bailey, 'Emergency Powers \& Pandemics' (n 25) in relation to some of the differences between regimes. 
Table 3: Public Health Orders and Enforcement Actions (as Reported) per 100,000 Population

\begin{tabular}{|c|c|c|c|c|c|c|c|c|c|}
\hline \multirow{3}{*}{ Year } & \multicolumn{9}{|c|}{ Reported Incidence of Use of Public Health Power per 100,000 population } \\
\hline & \multirow[b]{2}{*}{ NSW } & \multicolumn{2}{|l|}{ QLD } & \multirow[b]{2}{*}{ SA } & \multirow[b]{2}{*}{ Tas } & \multirow[b]{2}{*}{ Vic } & \multirow[b]{2}{*}{ WA } & \multirow[b]{2}{*}{ ACT } & \multirow[b]{2}{*}{ NT } \\
\hline & & $\begin{array}{l}\text { Environ. } \\
\text { Health }\end{array}$ & $\begin{array}{l}\text { Notifiable } \\
\text { Conditions }\end{array}$ & & & & & & \\
\hline 2004 & 0.06 & & & & & & & & 0.49 \\
\hline 2005 & 0.03 & & & & & & 0.10 & 0.30 & 0.48 \\
\hline 2006 & & & & & & & & & 0.47 \\
\hline 2007 & & & & & 1.01 & & & 0.29 & 0.46 \\
\hline 2008 & & 0.07 & & & 0.40 & & 0.14 & 0.29 & \\
\hline 2009 & 0.06 & 0.11 & 0.04 & & 0.20 & 0.02 & & & \\
\hline 2010 & 0.06 & 0.13 & 0.02 & & 0.39 & 0.09 & & & \\
\hline 2011 & & 0.04 & & & & 0.07 & & 0.27 & 1.29 \\
\hline 2012 & 0.03 & 0.04 & & & 0.78 & 0.11 & 0.20 & & 0.42 \\
\hline 2013 & & 0.23 & & & & 0.07 & & & 0.41 \\
\hline 2014 & & 0.27 & & & & 0.03 & & & 0.00 \\
\hline 2015 & & 0.27 & 0.08 & & & 0.05 & & & 0.41 \\
\hline 2016 & & & & & 0.19 & 0.05 & 0.12 & & 0.41 \\
\hline
\end{tabular}

Perhaps surprisingly, jurisdictions that have smaller general populations, and smaller populations of those at-risk of contracting HIV (eg, men who have sex with men, injecting drug users) and potentially of the risk of contracting TB (eg, high rates of international tourism or travel) seem to utilise coercive powers more frequently, and often more consistently, than jurisdictions like NSW, Victoria and Queensland that have larger general populations and populations of those 'at-risk'.

This variation in rate is a feature of which jurisdictions themselves seem to currently lack awareness. For example, Tasmanian officials acknowledged their jurisdiction had a smaller population than others but also described their use of public health powers as resulting in a 'small number of orders/directions issued 
in Tasmania'. ${ }^{145}$ Yet, from the data reported here, their utilisation rate is one of the highest in the country.

Beyond variation in utilisation, one further area of significant variation relates to record keeping practices of different jurisdictions. Only Queensland attempts to maintain a register of public health orders or enforcement actions. ${ }^{146}$ In discussion with NSW, the potential for a register was raised with the jurisdiction, and NSW has since announced reforms for reporting that would necessitate the maintenance of a form of register. ${ }^{147}$ Victoria, a jurisdiction that has had its public health records made subject to warrants and police raids, revealed that it did not maintain a register or similar record. Instead, information is filed in individual hardcopy records maintained by the Department of Health and Human Services. South Australia similarly reported that it did not maintain a $\log$ or record of orders. Specifically, the relevant officer wrote that: 'We do not keep a $\log$ of interventions, and even if we did I would not be prepared to release the information'. ${ }^{148}$

\section{The Lack of Publicly Available Information}

A fundamental barrier to the aims of the project related to record keeping. Although explicit details regarding record keeping practices were not always made clear, it seems that most, if not all, jurisdictions fail or have at some point failed to maintain adequate records of the use of public health powers. South Australia, the Northern Territory, NSW, the ACT, Western Australia and Victoria all acknowledged that they did not maintain a register or similar record of orders. Queensland Health has maintained a register since approximately 2013; however, the jurisdiction noted that the information in that register did not represent the full extent of the use of public health orders. ${ }^{149}$ It seemed that, in most instances, the requests prompted the production of a new document summarising the frequency of use of public health orders, not one already produced or maintained for the purposes of internal reporting or review by the relevant minister or other person. However, it may be that this approach to record keeping plays a protective role. Rather than 'lax', the decision to not maintain a register may well materially protect those subject to intensified public health powers from other forms of legal process. As illustrated by the incident noted

145 Email from Public Health Services, Tasmanian Department of Health and Health and Human Services, Acting Director of Public Health to David Carter, 27 July 2017, [1].

146 Although officers acknowledged that the data held in that register or system is incomplete.

147 NSW Government, Ministry of Health, 'Public Health Act 2010 Statutory Review Discussion Paper' (Discussion Paper No SHPN (LRS) 160132, 2016) 43-5<http://www.health.nsw.gov.au/legislation/ Documents/discussion-paper-public-health-act-2010-review.pdf $>$; NSW Government, Ministry of Health, Report on the Statutory Review of the NSW Public Health Act 2010 (Statutory Report, 17 November 2016) <https://www.parliament.nsw.gov.au/la/papers/Pages/tabled-paper-details.aspx?pk=69962> ('Report on the NSW Statutory Review'); Public Health Amendment (Review) Bill 2017 (NSW) sch 1 [56], insertion of s 131A.

148 Email from Communicable Disease Control Branch, SA Health, Director of Communicable Disease Control Branch to Starla Hargita, 10 November 2015, [2].

149 This seems unlikely in the case of Victoria, where the Chief Health Officer is required to make a report of the number of orders and the reasons for making them on an annual basis: see Public Health and Wellbeing Act 2008 (Vic) s 143. 
above regarding the subpoena of Victorian Department of Human Services records, the information collected and maintained regarding those subject to orders played a direct role in subsequent criminal prosecution.

A second significant challenge was the question of the 'sensitivity', 'privacy' or 'confidentiality' of information associated with the making of an order. As an officer of the South Australian government put it:

These are legal processes, they are highly personal and confronting for the individuals involved, and I would not risk the cooperation we receive from a range of people by having even de-identified numbers and outcomes published. South Australia is a small jurisdiction and some people would inevitably be identified. ${ }^{150}$

Given the potential sensitivity of information relating to the exercise of these powers, it may be that enhanced public reporting and transparency will require a flexible approach. For example, rather than frequent publication, jurisdictions might choose to make information available upon request, especially to interested parties, academics or other key stakeholders, redacting and summarising the use of powers as many have done in this instance. However, cultures of engagement and openness to the request for information regarding public health orders vary so significantly between different jurisdictions that this seems unworkable based on the experience of this research project. ${ }^{151}$ For example, NSW and Tasmania released information by administrative action with no other process required. The ACT indicated an openness to engage in the process and to consider release by administrative action, but subsequently requested that a FOI request be made in order to guide decision-making through an established process. Queensland offered assistance in relation to navigating its devolved system of public health powers, and noted the potential availability of some data through researcher-access mechanisms, ${ }^{152}$ but ultimately did not provide information through administrative action. A subsequent FOI application to the Department of Health and the most relevant Local Hospital and Health Service ('HHS') led to release of documents, but resources were not available to make FOI requests of each HHS or local government. South Australia, the Northern Territory and Western Australia explicitly refused release by administrative action, each for reasons accounted for in Part III(B) above. A FOI request was made to Western Australia. The request was successful and was also subject to the most extensive process of negotiating and reshaping the FOI request - assistance that was welcomed by the researchers but which took a lengthy period of time and specialist knowledge to complete. South Australia and Victoria completely refused any requests, administrative or otherwise; South Australia still with an outstanding and unprocessed FOI request lodged in May 2017. South Australia and the Northern Territory were the most cautious in their response to requests for information, making the engagement difficult to

150 Email from Communicable Disease Control Branch, SA Health, Director of Communicable Disease Control Branch to Starla Hargita, 10 November 2015.

151 See Appendix A.

152 As the scope of the research project was to engage in mechanisms related to publicly available information, namely publication by authorities, administrative action or FOI, this approach was not taken up at this time. 
maintain and at times oppositional when compared with the engagement with other jurisdictions.

Perhaps of most concern for any form of voluntary or request-based approach is the number of jurisdictions that voiced strong opposition to the potential public reporting of this data. South Australia, the Northern Territory, Tasmania, and Western Australia each expressed, in different ways, an opposition to the reporting of this information. South Australia is a notable leader in this regard thus far the only jurisdiction to refuse the release of any information relating to the use of these powers. As a consequence we are left with no way of knowing anything about South Australia's practices in relation to public health orders and similar activities. South Australian officials were the most strident in their opposition to the request for information, writing at one time that ' $[w] e$ [South Australia] do not keep a log of interventions,' then immediately foreclosing the potential for cooperative release of other information by writing 'and even if we did I would not be prepared to release the information'. ${ }^{153}$ Tasmania, on the other hand, represents a more balanced approach; while maintaining firm opposition to releasing disaggregated or case-level information, Tasmania did release a numerical summary of the use of public health powers, aggregated by year, thoughtfully justifying its decision-making process on the grounds of protecting patient confidentiality within the context of a smaller state population. By way of contrast, NSW provided swift reporting of data, despite having to draw together information from a range of sources. It was also the only jurisdiction that expressly committed to review the possibility of maintaining a limited but ongoing register in relation to the use of these powers following the requests made as part of this research. Since that time, the Ministry of Health has undertaken that the Public Health Act 2010 (NSW) be amended to require the Ministry to report the number of public health orders made in its Annual Report. ${ }^{154}$

\section{CONCLUSION}

The collection and analysis of the recent use of public health orders reported here was framed against the cases of Sharleen Spiteri and Lam Kuoth. The particular way that they were subjected to coercive public health powers raised questions regarding coherence with ethical frameworks that are used to justify these coercive measures, adherence to legal structures and safeguards that provide principled limits to their use, and more general questions of proportionality and arbitrariness. Given their status as representing the bulk of what we know of the exercise of these highly elastic and extraordinary powers, knowing whether Spiteri and Kuoth were dramatic 'outliers' in the exercise of public health powers in Australia or something more representative is important.

153 Email from Communicable Disease Control Branch, SA Health, Director of Communicable Disease Control Branch to Starla Hargita, 10 November 2015. 
To do so meant collecting information on the use of these powers across the nation. The result of that exercise reported here reveals some serious concerns about the use of these powers. This includes, amongst other things, evidence of the indefinite detention of multiple individuals by public health authorities, public health orders made without time limits and that have never been rescinded, and the practice of 'pre-emptive' warrants issued for the arrest and detention of individuals. So, too, does this research reveal a pronounced resistance to the disclosure of the use of these powers by a number of jurisdictions, and a failure to maintain adequate records of their use by others. Many of these instances may well be lawful. Many may well be justified on clinical, public health and biosecurity grounds. However, without greater detail, transparency and accountability, the public, interested parties and those subject to these coercive powers will be unable to gauge the lawfulness or justifiability of this exercise of executive power.

In the absence of a more complete account of the use of these powers, what has been revealed in this research reinforces concerns that cases like Spiteri and Kuoth are not merely dramatic outliers in this area of practice. Greater transparency regarding other orders may well counterbalance that interpretation, however, until such time that this is achieved, there seems little else that can be concluded from the records available.

Whilst greater transparency would facilitate better evaluation of the use of these powers, there are also important normative reasons for such transparency. Public health orders are administrative actions of the state. While they are usually initiated, managed and enforced by medical practitioners, and Chief Health Officers and others who may make these orders or participate in their execution are generally registered health practitioners or public health professionals, this feature does not render their character any less administrative. In the exercise of these powers, these persons - health practitioners or otherwise - are exercising the power of the state. This brings with it powers to coerce and enforce a clinical or public health opinion in ways not available to medical practitioners or public health professionals in any other context. The public health or medical content of an order does not render their character any less an exercise of executive power. Given that the breadth of public health and human biosecurity powers are so wide, and the potential seriousness of the deprivation of liberty that accompanies their use is so grave (even when legal), a proactive and detailed disclosure of these activities by the state seems justified on the grounds of public interest arguments for transparency and accountability of executive action, in addition to the gains a system of ongoing voluntary and cooperative disclosure might produce for public engagement in support of public health efforts.

The research reported here demonstrates the need for Australian governments to implement a new approach to transparency and public accountability in the use of these public health powers. Such disclosure may justify a series of efforts to safeguard the identity of those subject to orders. Whilst this is not the venue to canvass a comprehensive solution, it seems that modified use of existing review and appeal mechanisms would potentially provide an enhanced level of 
transparency and public accountability needed in this field. This could be achieved by making compulsory an early application of existing independent review and confirmation of public health orders by the relevant tribunal or court. ${ }^{155}$ This would, in effect, bring procedures for the exercise of public healthrelated powers into greater harmony with those that exist in relation to involuntary mental health treatment. Whilst the detail of such a proposal is beyond the scope of this article, the potential benefits are worthy of further study. For one, it is clear that despite very good engagement by some jurisdictions, it seems that a voluntary or request-based approach will not suffice to provide meaningful and ongoing transparency or public accountability for the use of these powers. Some jurisdictions did not release any information, many did not release all information, and, perhaps rightly, the information that was released was insufficiently detailed to facilitate a truly meaningful review of government action. Utilising existing mechanisms in a compulsory and early manner would include the benefit of independent review itself, as well as potential upstream effects on the quality of decision-making and record keeping that compulsory independent review would likely create. So, too, would it bring with it open public hearings, and the potential to develop better practice and procedure through the accumulation of experience by both review bodies and decisionmakers. This would also bring with it the potential to import the long-standing privacy protections and processes that are used in the context of mental healthrelated review, where options for closed hearings and restrictions on the publication of names, identifying information or other sensitive information are well established.

The power wielded by public health officials through the public health Acts is potentially immense, and the use of those powers should be acknowledged, lawful, transparent, auditable and justified. Yet, as noted above, no account of their use was found in the scholarly or professional literature. More concerning, no regular account or justification of their use is provided by the state. While public health powers are subject to administrative review, and in some jurisdictions are subject to forms of judicial oversight, ${ }^{156}$ violations of administrative justice in relation to coercive public health powers may bring with them consequences that cannot be undone.

155 The model in NSW in relation to orders made relating to Category 5 conditions (HIV) may be a helpful model here. See Public Health Act 2010 (NSW) where an order relating to HIV may be made for up to three business days in duration (s 63), which is far shorter than the 28-day limit otherwise imposed on most other orders. The relevant administrative appeals tribunal (NCAT) may confirm an order (s 64), should there be a need for it to last for more than three business days.

156 The regimes differ quite markedly between different jurisdictions. These will be accounted for in forthcoming research on the variability between review and oversight of these powers in Australia. 


\section{APPENDIX A}

Table 4: Scope of Request

\begin{tabular}{|c|c|c|}
\hline Jurisdiction & \multicolumn{2}{|l|}{ Scope of Request } \\
\hline \multirow{3}{*}{ New South Wales } & Time Period & 2004-14 inclusive. \\
\hline & Sources of Law & $\begin{array}{l}\text { Public Health Act } 2010 \text { (NSW) and/or Public Health Act } 1991 \\
\text { (NSW). }\end{array}$ \\
\hline & Request Method & Successful Administrative Request. \\
\hline \multirow{3}{*}{$\begin{array}{l}\text { Australian Capital } \\
\text { Territory }\end{array}$} & Time Period & 2004-15 inclusive. \\
\hline & Sources of Law & Public Health Act 1997 (ACT) or under any other power. \\
\hline & Request Method & $\begin{array}{l}\text { Administrative Request. Successful FOI Application (following } \\
\text { advice from ACT Health to make a FOI Application). }\end{array}$ \\
\hline \multirow[b]{3}{*}{ Queensland } & Time Period & 2004-15 inclusive. \\
\hline & Sources of Law & $\begin{array}{l}\text { Public Health Act } 2005 \text { (QLD) and any associated regulations or } \\
\text { powers (see especially ss } 21-46 \text { and as to authorised officers, } \\
\text { see especially ss } 376-84 \text { of the Public Health Act } 2005 \text { (QLD). }\end{array}$ \\
\hline & Request Method & $\begin{array}{l}\text { Administrative Request } 1 \text { (DoH, 2016): Advised that no-state- } \\
\text { wide registry available, however, Local Health and Hospital } \\
\text { Services would maintain this information. } \\
\text { Administrative Request } 2 \text { (DoH, 2017) in relation to HIV Public } \\
\text { Health Team based in the Department of Health: advised of the } \\
\text { Queensland Health data access system for researchers. } \\
\text { Advised of the 'MAPLE system' maintained by the Health } \\
\text { Protection Branch that captures (some) public health powers } \\
\text { compliance information. } \\
\text { FOI Request (DoH and Select HHSs, 2017): advised that due to } \\
\text { devolved powers to gain an 'accurate picture of the use of Public } \\
\text { Health Orders, you may wish to contact all } 72 \text { local governments } \\
\text { in Queensland'. Freedom of Information application to } \\
\text { Queensland Health, Metro South Hospital and Health Service, } \\
\text { Cairns and Hinterland Hospital and Health Service. FOI } \\
\text { processed by all. Results from Metro South HHS and } \\
\text { Queensland Health, Cairns and Hinterland HHS advised all } \\
\text { public health orders managed centrally. }\end{array}$ \\
\hline Victoria & Time Period & 2004-15 inclusive. \\
\hline
\end{tabular}




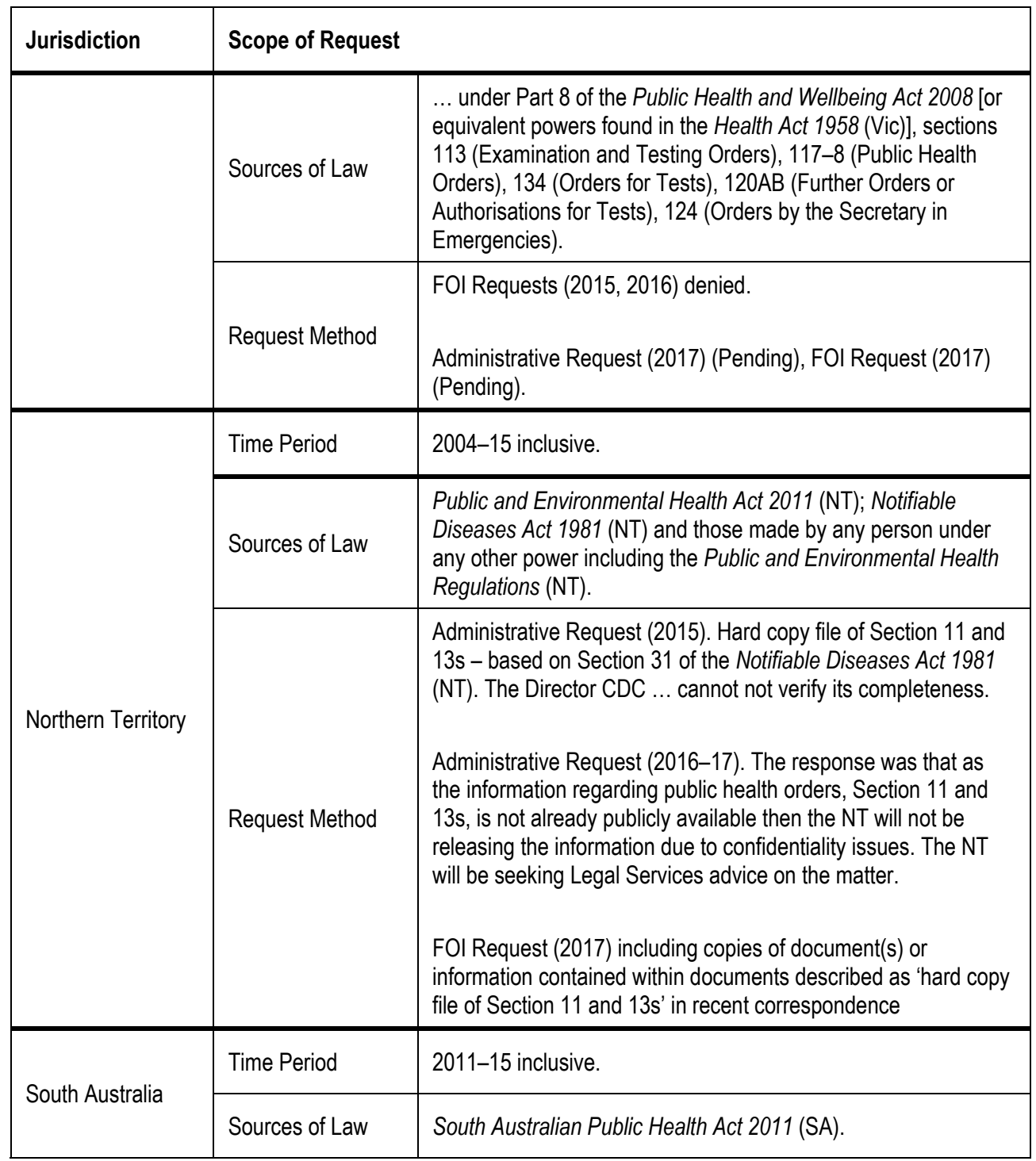




\begin{tabular}{|c|c|c|}
\hline Jurisdiction & Scope of Request & \\
\hline & Request Method & $\begin{array}{l}\text { Administrative Request (2015). Response: '[T]he information } \\
\text { you are seeking is not in the public domain. We do not keep a } \\
\text { log of interventions, and even if we did I would not be prepared } \\
\text { to release the information. These are legal processes, they are } \\
\text { highly personal and confronting for the individuals involved, and } \\
\text { I would not risk the cooperation we receive from a range of } \\
\text { people by having even de-identified numbers and outcomes } \\
\text { published. South Australia is a small jurisdiction and some } \\
\text { people would inevitably be identified.' (Email from Dr Ann } \\
\text { Koehler, Director CDCB to C Starla Hargita (Research } \\
\text { Assistant), } 10 \text { November } 2015 \text { 4:08PM). } \\
\text { FOI Request (May/June 2017) (Pending). No response received } \\
\text { from the jurisdiction. Follow-up made October } 2017 \text {. } \\
\text { Acknowledged receipt. No response. }\end{array}$ \\
\hline \multirow[b]{3}{*}{ Western Australia } & Time Period & $\begin{array}{l}2004-17 \text { inclusive. Acceded to request to revise scope to } 2012- \\
17 \text {, subsequent request made for } 2004-11 \text { inclusive. }\end{array}$ \\
\hline & Sources of Law & $\begin{array}{l}\text { Health Act } 1911 \text { (WA), and the Health (Miscellaneous } \\
\text { Provisions) Act } 1911 \text { (WA) and Public Health Act } 2016 \text { (WA) and } \\
\text { those made by any person under any other power including the } \\
\text { associated regulations or under any other power. }\end{array}$ \\
\hline & Request Method & $\begin{array}{l}\text { Administrative Request (2015-17). Eventually: 'The WA } \\
\text { Department of Health does not publish information on public } \\
\text { health orders, so l'm unable to assist with the request'. } \\
\text { FOI Request (2017). Request to revise scope from } 2004 \\
\text { onwards to } 2012-17 \text { at the request of the relevant business unit } \\
\text { (the longer period was described as encompassing an estimated } \\
150-200 \text { pages of documents, and thus would divert a } \\
\text { substantial and unreasonable portion of the agency's resources } \\
\text { away from its other operations). Revised } 2012-17 \text { scope } \\
\text { resulted in production of approximately } 2.5 \text { pages of documents } \\
\text { per year of the request's scope. Second request (9/17) made for } \\
\text { remainder of original time period scope of } 2004-11 \text { inclusive. } \\
\text { (Pending). }\end{array}$ \\
\hline \multirow[b]{2}{*}{ Tasmania } & Time Period & 2004 onwards. \\
\hline & Sources of Law & $\begin{array}{l}\text { Public Health Act } 1997 \text { (Tas) or the HIV/AIDS Preventive } \\
\text { Measures Act } 1993 \text { (Tas) or associated regulations or } \\
\text { subordinate legislation. }\end{array}$ \\
\hline
\end{tabular}




\begin{tabular}{|l|l|l|}
\hline Jurisdiction & \multicolumn{2}{|l|}{ Scope of Request } \\
\hline & Administrative Request $(2015,2016-17)$. No Response. \\
& Request Method & $\begin{array}{l}\text { FOI Request (Submitted: 1/5/2017. No response. Request } \\
\text { update 30/6/17 to FOI Officer. Release of information by } \\
\text { administrative action in response to earlier administrative } \\
\text { request 30/6/2017. No response to RTI request as at } \\
27 / 9 / 2017) .\end{array}$ \\
\hline
\end{tabular}

